\title{
Competition and Product Quality in the Supermarket Industry
}

\author{
David A. Matsa*
}

July 6, 2009

\begin{abstract}
This paper analyzes the effect of competition on a supermarket firm's incentive to provide product quality. In the supermarket industry, product availability is an important measure of quality. Using U.S. consumer price index microdata to track inventory shortfalls, I find that stores facing more intense competition have fewer shortfalls. Competition from Wal-Mart - the most significant shock to industry market structure in half a century - decreased shortfalls by up to 24 percent. The risk of customers switching stores appears to provide strong incentives for investments in product quality.
\end{abstract}

JEL Classifications: D40, G31, L15, L81

Keywords: product quality, competition, monopoly, big-box, inventory management, stockout

\footnotetext{
* Kellogg School of Management, Northwestern University, dmatsa@kellogg.northwestern.edu. This work was conducted in coordination with the U.S. Bureau of Labor Statistics (BLS) under an Agency Agreement. I am indebted to Bill Cook, Craig Brown, Mark Bowman, Dan Ginsburg, and others at the BLS who have been extremely helpful throughout this project, and to Mark Bils for sharing portions of his computer code and insight into the data. I also want to thank Mike Mazzeo and Nancy Rose for helpful comments. I am grateful to Garry Van Siclen and Trade Dimensions for providing the supermarket establishment data, and to Thomas Holmes for the information on Wal-Mart store openings. This research would not have been possible without the support of the George and Obie Shultz Fund and the National Science Foundation (Grant No. SES-0551097). The BLS pledges confidentiality to voluntary respondents in the Consumer Price Index (CPI) sample; no inferences should be made from this paper as to whether or not a specific firm is included in the CPI sample. Any opinions, findings, or conclusions expressed herein are my own and do not necessarily reflect the views of the BLS.
} 
Increasingly over the last few years, competition for consumers' food dollars has intensified....The Company believes its competitive advantages include convenient locations, the quality of service it provides its customers, competitive pricing, product variety and quality and a pleasant shopping environment.

Ingles Markets, Inc. 10-K, September 27, 2008

\section{Introduction}

In most consumer markets, there is more to shopping than finding the lowest price. A product's quality can have large effects on demand and consumer welfare. Although theory has long recognized that firms with market power may reduce their products' quality in order to save costs and maximize their profits (Chamberlin 1933; Abbott 1955), empirical research and competition policy tend to focus almost exclusively on price setting (Draganska, Mazzeo, and Seim 2009). While the potential for competition to have a significant effect on product quality is recognized in theory, its empirical importance is much less clear.

This study focuses on the connection between competition and product quality in the supermarket industry. In the retail sector, a firm's "product" is the shopping experience it provides its customers. Like for physical products, retail product quality has many dimensions, including the store's cleanliness, its checkout speed, the courteousness of its staff, and the depth of its product assortment. The particular dimension of quality that I examine in this paper is whether a supermarket reliably has its customers' preferred products in stock when they want to make a purchase.

As an important determinant of customer satisfaction, maintaining a reputation for product availability is a key strategic issue throughout the retail sector. Estimates suggest that 8.2 percent of the items a grocery retailer carries are not in inventory on a typical afternoon and that this is a major cause of customer dissatisfaction (Andersen 1996; Roland Berger 2002). In fact, consumer surveys find that frequent inventory shortfalls ("stockouts") and limited product variety are the number one cause of dissatisfaction among supermarket shoppers (FMI 1994b).

Stockouts can be costly to retailers in the current period and especially in future periods. Customers' immediate substitution to other products or stores upon encountering out-of-stock items is estimated to cost the average grocery retailer 1.7 to 3.1 percent of current period sales (e.g., Andersen 1996; Emmelhainz et al. 1991; Anupindi et al. 1998). Aggregating over the supermarket industry, this translates to $\$ 6$ billion to $\$ 12$ billion in lost sales per year. ${ }^{1}$ An even greater risk to the firm is that some consumers will shift their future shopping to competing stores. Although these future costs are difficult to

\footnotetext{
${ }^{1}$ This figure aggregates retailers' lost intended purchase expenditure, but it does not include the sales gained by retailers because of inventory shortfalls at other stores. The number is meaningful from the perspective of an individual profit-maximizing retailer, but not from the perspective of the industry. The decrease in aggregate supermarket sales, which includes gains in addition to losses, is likely much lower.
} 
quantify, studies find they have the potential to be substantial (e.g., Straughn 1991; Fitzsimons 2000; Anderson et al. 2006). To avoid these costs, a typical supermarket firm spends twice as much on inventory as on advertising. ${ }^{2}$

Pressure from competition places countervailing incentives on a retail firm's optimal level of availability. This tradeoff and other factors affecting optimal availability are discussed in Section 2. On one hand, lower profit margins reduce the immediate costs of losing a sale because an item is out of stock. But greater competition also increases the future costs if dissatisfied consumers are more likely to switch stores for their future shopping needs. Which of these incentives dominates is an empirical question. This ambiguity is common in theories of quality competition (for example, see Spence 1975). Schmalensee's (1979) review of the theoretical literature on quality competition concludes "there is an obvious need for empirical work to confront the implications of the theoretical literature with data."

To measure inventory shortfalls, this study takes advantage of a unique data set that was hand collected by the U.S. Bureau of Labor Statistics for use in constructing the consumer price index (CPI). Section 3 describes these data. The data are unique in that they contain information that can be used to measure supermarket product availability at the store-product level, even for firms that do not report financial information to the Securities and Exchange Commission (SEC). These disaggregated microdata allow me to examine variation in product availability across products and stores - even within the same firm - to shed light on the economic forces that affect expenditures on product quality.

I examine the empirical connection between competition and supermarket quality using two complementary approaches. First, in a descriptive analysis, I measure the conditional correlation between local retail competition and stockouts. These results control for market and store characteristics as well as an extensive set of fixed effects, including indicators for firm, product category, metropolitan area, and date. I find that stockouts are negatively correlated with competition. Supermarkets that face competition in their census tract average 5 percent lower stockout rates than otherwise similar stores, suggesting that competition increases firms' incentive to provide quality.

To address the possibility that these correlations are confounded by endogeneity or an omitted local market characteristic, I employ a second empirical approach. I examine the effects of Wal-Mart's entry into the supermarket industry - the most significant shock to industry market structure in half a century. Section 4 describes these developments. Within fourteen years of opening its first supercenter (stores selling both general merchandise and a full-line of groceries) in 1988, Wal-Mart has become the largest grocery retailer in the U.S. and the first truly national grocery chain. I exploit time series patterns in Wal-Mart's entry into local grocery markets to examine how competing supermarkets adjust their

\footnotetext{
${ }^{2}$ Using an inventory carrying cost of 25 percent (Brooks 1972), the average Compustat firm in 2005 spent 1.6 percent of sales on financing and maintain inventory, compared to 0.8 percent on advertising.
} 
quality in response. After controlling for market and even store fixed effects, the specific timing of WalMart's entry represents an exogenous shock to the competitive landscape of these markets. Consistent with this interpretation, there are no pre-existing differences or trends in product availability in these markets before Wal-Mart's entry.

Section 5 documents how supermarkets' product availability changes after Wal-Mart comes to town. The analysis finds that pressure from competition can have significant effects on the quality of a firm's products. When facing competition from Wal-Mart, stockouts decrease on average by about 8 percent. The effect is long-lived and robust to including store fixed effects, indicating that the additional stockouts are not attributable to demand miscalculations or attrition that may have followed Wal-Mart's entry. Furthermore, I separate products based on their distribution channel and find that competition has no impact on stockouts for product categories for which inventory is directly managed by manufacturers' distributors, whose optimal stockout rate is unlikely to change with retail market structure. There is also no evidence of incumbents decreasing product variety after competition increases.

Heterogeneity in these effects across stores and markets further supports the role of competition in improving quality. I examine whether there are greater reductions in stockouts among stores that are more likely to lose their customers to Wal-Mart, as measured along two dimensions. First, competition from Wal-Mart typically represents a more direct challenge to large regional chains that feature extensive selections of products than to independent stores that serve niche consumer markets. Second, because Wal-Mart caters to low income consumers with a low price, low service format, supermarkets located in lower income areas within a given supercenter's catchment area are likely to be most affected when a supercenter opens. I find that the decrease in stockouts is indeed related to both factors. In fact, the average stockout rate decreases by 24 percent among chain stores in low income areas.

This analysis focuses on product availability in the supermarket industry, but it likely also has implications for other dimensions of product quality at these and other firms. Supermarket executives see the stockout rate as a barometer of the whole operational side of the business (Progressive Grocer 1968, p. S4). Empirically, I confirm that supermarket inventories are correlated with other dimensions of product quality: chains that rarely run out of inventory are also cleaner, have more courteous staff, and have faster checkouts. If competition reduces stockouts, these other dimensions of product quality may improve as well. In fact, case studies suggest that supermarket chains attempt to differentiate themselves from WalMart by improving quality along many dimensions, including increasing product assortments, offering fresher meat and produce, and maintaining cleaner, more attractive displays (Carré, Tilly, and Holgate 2009).

This article complements a small number of empirical papers that examine the connection between quality provision and market concentration in other settings. For example, Domberger and Sherr 
(1989) examine markets for real estate transfer services in England and Wales, and Mazzeo (2003) examines on-time performance in the US passenger airline industry. These studies tend to find positive correlations between competition and quality, but the data analyzed leave some questions about causal inference. ${ }^{3}$ This paper addresses those concerns by exploiting variation at the product level in individual stores that experience different shocks to their competitive environment. The shocks vary in their magnitude and hit at different times. By studying how competition affects inventory strategies across these markets and stores, and for products with different characteristics, I am able to make a strong argument for competition causing supermarkets to improve their quality.

This work also extends previous research on retail inventory strategy. An extensive theoretical literature investigates optimal retail inventory policies and stockout avoidance (e.g., Hall and Porteus 2000; Dana 2001; Dana and Petruzzi 2001; Gaur and Park 2007), but until recently there has been little data on the empirical relevance of these models. Based on a large-scale field test at a catalog company, Anderson, Fitzsimons, and Simester (2006) conclude that inventory policy at the firm they study fails to account for the future opportunity costs of a stockout. Building on that result, Matsa (2009) shows that highly leveraged supermarket firms, which are likely to heavily discount the future costs, are more likely to run out of inventory. This is the first empirical paper (that I know of) to examine the connection between market structure and inventory policy.

\section{Retail product availability and competition}

Maintaining optimal product availability is an important dimension of store quality in the retail sector. Studies indicate that 8.2 percent of a grocery retailer's items are out of stock on a typical afternoon and that frequent stockouts and limited product variety are the number one cause of dissatisfaction among supermarket shoppers (Andersen 1996; Roland Berger 2002; FMI 1994b). Reducing stockouts is cited as being as important to store image as flashy customer attractions such as new buildings, remodeling, attractive decor, advertising, promotion, and merchandising (Progressive Grocer 1968, p. S1). Nevertheless, stockout rates vary dramatically across stores and markets, and high in-stock levels are reported to provide retailers with a significant competitive advantage (Andersen 1996).

The frequency of retail stockouts is largely determined by ordering and stocking decisions made at the regional and store levels. Studies find that the vast majority of supermarket stockouts are caused

\footnotetext{
${ }^{3}$ Domberger and Sherr (1989) find that the threat of new entry caused by liberalization was associated with increases in customers' self-reported satisfaction with their attorney for property sales but not for property purchases. Based on only time series variation, it is unclear to whether these measures of satisfaction reflect the rapid acceleration in house prices over the period rather than an actual change in the quality of legal services provided. Mazzeo (2003) finds that average flight delays are longer in more concentrated airline markets. Based only on cross-sectional variation, it is possible that unobserved market characteristics that cause delays also deter entry from additional carriers.
} 
within the store rather than by other parties in the vertical chain: 51 to 73 percent of out-of-stocks due to inaccurate forecasting (e.g., underestimating demand) and ordering errors (e.g., failing to sufficiently monitor the shelf inventory and not reordering when demand exceeds forecast) and another 8 to 22 percent due to failing to restock shelves with available backroom or display inventory (Andersen Consulting 1996; Gruen et al. 2002). A store's investments in inventory and staff assigned to shelf monitoring thus have the most direct impact on its product availability. Because these decisions can be adjusted in real time, an optimizing retailer typically takes retail market structure as given when making investments in product availability.

Although no retailer typically wants to run out of inventory, reducing stockouts is costly and maintaining 100 percent product availability in a supermarket is certainly not optimal. Optimal stocking decisions trade off expenditures on both inventory costs and shelf monitoring costs for the present value of expected lost profits from running out of inventory. Running out of inventory can reduce profits in both the short and long run. Upon finding that an item is out of stock, consumers substitute by purchasing an alternative item (which reduces the intended purchase expenditure by 0.4 percent), shopping at another store or forgoing the purchase (a 1.3 percent expenditure reduction), or delaying purchase (a 1.3 percent reduction; Andersen 1996). Lost sales from immediate substitution on out-of-stock items is estimated to cost the grocery industry $\$ 6$ to 12 billion annually. ${ }^{1}$

Importantly, a store that runs out of inventory not only loses profits from current purchases of the product but also risks affecting consumers' future shopping behavior. Switching supermarkets is thought to be costly for shoppers, who are accustomed to a particular store's layout and a regular food shopping routine. Because consumers only reluctantly change their routines, a small but important risk of running out of inventory is that it may cause some customers to switch their regular business to another retailer (Anderson et al. 2006). Consumer surveys find that stockouts are a significant factor in consumers' decisions to switch primary grocers (Andersen 1996). For this reason a store's provision of reliable product availability can be thought of as an investment in future market share.

A store's optimal level of product availability thus depends on customers' propensities, when facing an out-of-stock item, to reduce current expenditures and to switch stores on future shopping trips. An increase in retail competition can affect these risks. Competition may reduce the short-run costs of running out of stock if profit margins decrease, making it less costly on the margin for customers to substitute to a lower margin product, delay purchase, or search elsewhere. But competition may also increase the long-run costs, because consumers will have additional options for their future shopping needs. Although a reputation for running out of stock frequently may irritate customers, it is not so costly for a store when customers other food shopping options are limited. Thus once another store opens 
nearby, a strong incentive can develop to improve quality and reputation for reliable in-stock performance.

Retailers' incentives in inventory management differ from those of the product manufacturers. When customers substitute brands upon encountering an out-of-stock item, the retailer only loses any difference in margin between the products, but the manufacturer loses profits from the sale entirely. On the other hand, the manufacturer may lose little when customers switch stores, while the retailer loses the sale entirely. Therefore, manufacturers do not share stores' incentive to offer greater product availability when retail competition increases. If manufacturers managed shelf inventory, increased retail competition would be unlikely to affect product availability.

Many factors besides competition and customer substitution and switching also affect a particular item's optimal stockout rate, including the price elasticity of demand, the wholesale cost, the inventory cost, and the variability of demand. Products for which demand is less elastic earn greater markups and are more valuable to keep in stock. Some products, such as refrigerated items, are more costly to inventory than shelf-stable products. And some products, such as many seasonal items, have less predictable demand.

The optimal rate also varies across retailers. In large stores, returns to scale in demand forecasting and order management may reduce the cost of providing product availability. Greater product variety may also reduce the inconvenience for consumers of encountering a stockout in these stores. The distance from a store's primary supplier may affect the store's optimal stockout rate, and technological advances and other changes over time may affect inventory costs. To control for these and other factors that affect the optimal rate of product availability, the empirical analyses of stockouts presented below controls for product category, store, and year-month fixed effects as well as a number of market, item, and time-varying store characteristics.

\section{Data and descriptive analysis}

\section{A. Data on retail stockouts}

Reliable data on supermarket product availability are rare; most food stores do not even keep systematic records on their availability (Andersen 1996). The most frequently cited statistics on the prevalence of stockouts come from an Andersen (1996) study, sponsored by the Coca-Cola Retailing Research Council. The authors performed daily audits of 7,000 items in eight product categories in ten demographically and regionally diverse stores for one month. Such isolated (and often localized) studies

do not lend themselves to either cross-sectional or longitudinal analysis at the store or market level. Due to the cost of conducting wider-scale audits, some studies have attempted to measure out-of-stocks using 
purchase scanner data (e.g., Gruen et al. 2002). But such studies risk confusing low availability with low demand, which would bias estimates (Dorgan 1997).

I obtain reliable data on stockouts from the CPI Commodity and Services Survey, which is used by the U.S. Bureau of Labor Statistics (BLS) to compute the consumer price index (CPI). To calculate the CPI, the BLS sends surveyors to record the prices of about 30,000 items sold at grocery stores each month, where each price is specific to a particular product at a particular establishment. Generally, a product must be available for purchase at the time the surveyor visits the establishment in order to be included in the CPI. If the product is unavailable for sale, the surveyor determines whether the establishment expects to carry the item in the future. Thus a product may be considered out of stock if it is not available for sale, it is continuing to be carried by the outlet, and it is not seasonally unavailable (Bils 2005). More details on the construction of these data are described in Appendix A.

Using these microdata, I examine observations on product availability at the item-store-month level from January 1988 through December 2004. Any particular item is sampled for at most 5 years: the full data set includes about 5 million observations on availability for almost 220,000 unique items at 11,500 stores in more than 8,000 census tracts and 147 metropolitan areas. I augment the CPI data with detailed store-level information from the Trade Dimensions Retail Site Database and demographic information on each store's census tract from the 2000 U.S. Census of Population and Housing. Summary statistics are reported in Table 1 . The average stockout rate among supermarket respondents is 4.3 to 5.3 percent. Two factors relating to BLS data collection procedures seem to explain why these estimates are lower than the 1996 industry estimate of 8.2 percent. First, CPI data are usually collected throughout the day on weekdays, whereas out-of-stocks are most prevalent in the afternoon and on Sundays (when they reach an estimated 10.9 percent; Andersen 1996). Second, for food items consumed at home, the BLS effectively does not record stockouts caused by store shelving issues (8 to 22 percent of stockouts; see Appendix A for details). While these factors affect estimates of the absolute level of stockouts, they are unlikely to bias estimates of changes in product availability caused by changes in stores' competitive environments.

Average stockout rates by day of the week are reported in Figure 1. Average stockout rates are greatest on Sundays (4.8 percent) and decline throughout the rest of the week. This general pattern is consistent with 13 different industry studies surveyed by (Gruen et al. 2002, p.14). Because the heaviest shopping usually takes place over the weekend, re-ordering and deliveries typically occur on Monday and Tuesday. Throughout the week, restocking and preparations for Saturday and Sunday promotions lead to lower stockout rates. After the heavy shopping on Saturday, stockout rates increase sharply on Sundays when labor is reduced, stores seldom take deliveries, and inventories runs out for items that are more popular than expected. 
Stockout rates also vary systematically across product categories. Figure 2 graphs average stockout rates by major product group. Average stockout rates are lowest for prescription drugs (0.9 percent) and fats and oils (1.4 percent), and they are highest for fish and seafood (8.3 percent), poultry (7.9 percent), and other fresh meat, fruit, and bakery products. On the whole, stockout rates are lower for shelf-stable than refrigerated or frozen products. Similar patterns are evident across more detailed product categories. Appendix Table 1 reports average stockout rates in each of 76 different product categories. There is significant variation in stockout rates even for product categories within the same major group. For example, cakes are out of stock 10.0 percent of the time, whereas cookies are out of stock only 3.5 percent; and ground beef is out 2.5 percent, while other beef and veal are out 12.5 percent. In the analyses that follow, I control for product category fixed effects at this more detailed level.

\section{B. Stockouts and competition and other market, store, and product characteristics}

Although rates of product availability calculated from the CPI data are certainly measured with sampling error, they seem to provide reliable estimates. Table 2 presents the conditional correlations of stockouts with various market, store, and product characteristics in a linear-probability multivariateregression framework. ${ }^{4}$ Each observation represents a particular item in a particular store on a particular day: the dependent variable equals 100 if the item is out of stock and 0 if it is in stock. In addition to the controls shown, the regression reported in Table 2 includes a set of fixed effects for each of the following: the firm, the product category, the metropolitan area, the day of the week, and the year-month. ${ }^{5}$ The standard errors are adjusted to account for contemporaneous and intertemporal within-market correlation in the error term.

A number of robust patterns emerge from the estimates presented in Table 2. First, the structure of retail competition is correlated with supermarket quality. As a measure of supermarket competition, I examine whether a store faces any competing stores in its census tract. On average, stores that face competition in their census tract have 5 percent lower stockout rates than other stores (evaluated at the mean; $p<0.01){ }^{6}$ A causal interpretation of this estimate implies that pressure from supermarket competition encourages improvements in quality. But it is also possible that an omitted variable, such as an unmeasured dimension of consumer preferences, leads to both greater competition and greater product

\footnotetext{
${ }^{4}$ Given the size of the data set and the large number of fixed effects, maximum likelihood estimation of a probit or conditional logit model is computationally infeasible.

${ }^{5}$ There is one firm fixed effect for all stores not affiliated with a chain (defined as 11 or more retail stores), which corresponds to 18.9 percent of the sample. Product category fixed effects are at the level of BLS entry level items. The sample includes items from approximately 75 grocery categories, ranging from breakfast cereal to eggs to laundry and cleaning products; Appendix Table A1 lists the complete set of product categories.

${ }^{6}$ Stockout rates at these stores average 21 basis points lower - a 5 percent decrease relative to the sample mean of 4.3 percent.
} 
availability in some markets. The analysis of Wal-Mart entry in the supermarket industry, presented below, aims to distinguish between these possibilities by examining the competitive responses to plausibly exogenous shocks to the competitive landscape of various local markets over time.

The importance of other market characteristics is also striking. Supermarkets located in census tracts with wealthier consumers offer greater product availability (fewer stockouts). Higher prices (and presumably margins) in these markets give firms an incentive to offer greater availability (Dana 2001). Markets with more senior citizens also have significantly fewer stockouts, likely because senior citizens with pronounced preferences and low time costs - are more likely to shop elsewhere when their preferred item is out of stock (Peckham 1963).

The stockout rates are also linked to store and product characteristics. Returns to scale seem to lead to lower stockout rates at larger stores, and stockout rates are greatest when a store is located far from its primary supplier. Stockout rates are also greater for seasonal items (items that are not offered for sale year-round), which is consistent with the demand for these items being less predictable. ${ }^{7}$

\section{Stockouts and other dimensions of store quality}

Observed rates of product availability are also correlated with other dimensions of supermarket quality. I obtain ratings of major supermarket chains from Consumer Reports magazine, which publishes the ratings based on tens of thousands of readers' responses to questionnaires (See Appendix A for details). Combining these ratings with the CPI data yields a sample of more than 2 million availability observations for 57 supermarket chains.

Conditional correlations of stockouts with various ratings from Consumer Reports are presented in Table 3. ${ }^{8}$ I regress the stockout indicator on each rating, fixed effects for product category, metropolitan area, day of the week, and year-month, and controls for the market, store, and product characteristics shown in Table 2. The standard errors are adjusted to account for within-firm correlation in the error term. The results show that the more highly rated chains are less likely to run out of inventory. Consumer Reports' overall satisfaction score summarizes readers' average satisfaction with store quality. While overall satisfaction is ostensibly rated on a 100-point scale, the actual ratings range from 63 to 87. The estimate, which is reported in Column (1), suggests that a 10-point greater overall satisfaction rating is associated with a lower stockout rate by 0.6 percentage points - a 13 percent reduction for the average firm $(p<0.01)$.

\footnotetext{
${ }^{7}$ The algorithm for identifying stockouts is structured to avoid classifying an unavailable item as a stockout when the item is out of season (see Appendix A for details).

${ }^{8}$ These results are also reported in Matsa (2009).
} 
In addition to having relatively high overall ratings, chains with low stockout rates are rated highly in more specific dimensions as well. Consumer Reports publishes separate ratings of supermarket cleanliness, staff courtesy, and checkout speed. Each of these ratings is on a 5-point scale, and their conditional correlations with the stockout rate are reported in Columns (2) through (4). A decrease in the stockout rate of 40 basis points (just under 10 percent of the mean) is associated with a 1.7 point increase in its rating for cleanliness, a 1.3 points for courtesy, and 1.3 points for checkout speed. ${ }^{9}$ A retailer's ability to keep products in stock seems to also be an indicator of their performance on other dimensions of product quality.

\section{Wal-Mart's entry into the supermarket industry}

Wal-Mart's entry into the supermarket industry shocked the structure of local grocery markets throughout the United States. Wal-Mart first experimented with adding a full-line of groceries to its general merchandise stores in 1988, branding these stores "supercenters." According to industry analysts, Wal-Mart originally added food in order to drive store traffic and sales of its general merchandise offerings by getting customers into its stores for weekly shopping rather than only a couple of times a month (Singh, Hansen, and Blattberg 2006; Carré, Tilly, and Holgate 2009). Wal-Mart has since grown to become the largest grocery retailer in the United States, currently operating more than 2,600 supercenters across the United States. In fact, groceries now account for 49 percent of Wal-Mart's domestic sales. Not surprisingly, Wal-Mart is seen as a serious threat to the traditional supermarket industry, with 80 percent of supermarket managers citing competition from supercenters as their biggest concern in the coming year (National Grocers Association 2003; Hausman and Leibtag 2007). ${ }^{10}$

Wal-Mart's success is widely attributed to a combination of technology and scale (Basker 2007). State of the art information technologies in distribution enable Wal-Mart to use frequent deliveries to support large stores at low cost. Adding additional product lines, such as groceries, both benefits from and further enhances this advantage, as delivery trucks use the additional product lines to support even more frequent deliveries without much additional cost (Holmes 2001). Economies of scale also put WalMart in a strong bargaining position with suppliers, as Wal-Mart accounts for 14 to 18 percent of sales from the major grocery manufacturers, including Kraft, Kellogg, and General Mills (Warner 2006).

Building on this competitive advantage, Wal-Mart stores feature a low price, low service, onestop-shopping format. For a majority of consumers, low prices are the "best thing” about Wal-Mart (Pew

\footnotetext{
${ }^{9}$ A one-point increase in a store's cleanliness rating is associated with 24 basis points fewer stockouts. Therefore, a 1.7 point increase in the cleanliness rating is associated with 40 basis points fewer stockouts (i.e., $40 / 24=1.7$ ). The other estimates are calculated in a similar manner.

${ }^{10}$ Although Kmart and Target, other large general merchandise retailers, have also added groceries to some of their stores, they have not grown nearly as fast (Graff 2006).
} 
2005). The broad selection of product lines - including groceries, clothes, house wares, and cosmetics also offer convenience. However, lower prices and increased convenience are partially mitigated by reduced product offerings, lower service levels, and other disamenities. Wal-Mart's low inventory costs and strong bargaining position with suppliers rely in part on its carrying a more limited assortment of brands and varieties of particular goods - i.e., it specializes in product breadth rather than depth (Basker 2007). With 100,000 people visiting an average supercenter each week, customers also criticize long lines and poor customer service (Pew 2005); reports find the stores' displays often messy and dirty, the aisles jammed with new stock waiting to be shelved (Callahan and Zimmerman 2003). ${ }^{11}$

Consistent with its product market strategy, Wal-Mart is more popular among lower income consumers. Fifty-three percent of people with annual incomes below \$30,000 shop at Wal-Mart regularly, compared to only 33\% of those with incomes above \$50,000 (Pew 2005). Basker (forthcoming) confirms that the likelihood of shopping at Wal-Mart falls with income. Using both crosssectional and time-series data, she finds that the average household spends more at Wal-Mart when its income falls. Singh, Hansen, and Blattberg (2006) find a similar pattern among supermarket customers that defect to Wal-Mart when a supercenter opens nearby. They examine high-frequency transaction data for one small town supermarket before and after Wal-Mart's entry, and find that low income consumers are more likely to shop less at the supermarket after Wal-Mart opens.

Competition in the retail food industry can be divided into two distinct submarkets: regional chains and independent stores. Ellickson (2006) shows that the chains' escalating investments in their distribution systems can create natural oligopolies in retail food markets. The chains build large stores that feature extensive selections of products, while independent stores offer narrower, more specialized selections of products serving niche consumer markets. In this framework, the entry of Wal-Mart's logistics expertise into groceries presents a more direct challenge to the large chains than to the niche independents.

Following previous research, I use counties as the relevant market for competition from Wal-Mart (e.g., Graff and Ashton 1994; Basker 2005; Jia 2008). Figure 3 shows the timing of Wal-Mart's entry into new grocery markets between 1988 and 2004. The store opening data is from Holmes (2008), which is based primarily on information posted by Wal-Mart on its web site plus additional data from Basker (2005). Supercenter expansion followed a similar geographic pattern to the expansion of Wal-Mart's general merchandise stores, starting in the central United States and radiating outward until supercenters reached nationwide (Basker 2007; Holmes 2008).

\footnotetext{
${ }^{11}$ Wal-Mart is also known for inferior offerings and low service in the meat department. After a group of meatcutters in east Texas voted to unionize in 2000, Wal-Mart reassigned its butchers to other jobs and turned to caseready, pre-packaged meat. The decision saved labor costs but left its meat counters with fewer choices and no customer service (Callahan and Zimmerman 2003).
} 
Because Wal-Mart locates its stores in markets where it expects to be profitable, cross-sectional estimates of the effects of Wal-Mart's entry are undesirable. An omitted variables bias is likely to affect cross-sectional estimates, because market characteristics that affect Wal-Mart's entry decision are also likely to affect supermarkets' expenditures on quality. Although a well-designed instrumental variables (IV) strategy could overcome this issue, finding an appropriate instrument has proven elusive. Basker and Noel (forthcoming) show that using either (i) the distance from Wal-Mart's nearest food distribution center or (ii) the presence of a pre-existing Wal-Mart discount store, violate the IV exclusion restriction and yield biased estimates. Basker and Noel (forthcoming) find instead that panel OLS regressions with market fixed effects provide the most reliable estimates of the effects of Wal-Mart's entry.

Relative to the other approaches, panel estimates with market fixed effects require weak conditions for causal interpretation. This approach allows for Wal-Mart's choice to enter a particular market to be endogenous. In the context of this paper, the estimates have a causal interpretation as long as, conditional on entry, the exact timing is uncorrelated with other determinants of incumbents' inventory policies. In support of this assumption, I find no pre-existing trends in the stockout rates of incumbent stores before they experience Wal-Mart entry (see Table 6 and Figure 4 below).

Table 4 reports summary statistics for supermarkets' characteristics in 1990, before Wal-Mart began entering the grocery industry in earnest. Supermarkets averaged just over 20,000 square feet of selling space, $\$ 170,000$ in weekly sales, 50 employees, and 7 checkout counters. About one in two supermarkets were part of a chain of 11 or more stores, and the average store shared ownership with 270 stores across 6 states. Stores that would and would not eventually face competition from Wal-Mart were mostly similar across these dimensions, in stark contrast to what would become the footprint of a typical Wal-Mart supercenter. According to data from Trade Dimensions, supercenters average 185,000 square feet of which about a third are devoted to groceries, $\$ 880,000$ in weekly grocery sales, 333 employees, and 28 checkout counters. With more than 2,600 supercenters across 48 states by 2009, Wal-Mart has become the first truly national grocery retailer.

\section{Results}

\section{A. Estimates of the overall effect}

Difference-in-difference comparisons provide a simple measure of how product availability changes among incumbent supermarkets after Wal-Mart enters a grocery market. Table 5 reports average stockout rates in 1988 and 1998, separately for markets that experienced Wal-Mart entry in that period and markets that did not. There was no difference in stockout rates in 1988 between the two groups. But ten years later, in 1998, stockout rates were approximately 1 percentage point, or 21 percent, lower in 
markets that experienced Wal-Mart entry during the intervening period. ${ }^{12}$ This difference-in-difference comparison, reported in the last row of Table 5, is economically meaningful and statistically significant.

A similar pattern is evident from longitudinal regression analysis that controls for a large set of store, market, and product characteristics. I use a fixed-effects framework to examine same-store changes in product availability leading up to and following Wal-Mart entry. The estimates reveal whether incumbent supermarkets alter their product availability, relative to stores in other markets, after Wal-Mart entry increases competition in their market. Using monthly product-level data from January 1988 through December 2004, I estimate a linear probability model of an item being out of stock: ${ }^{13}$

$$
\text { STOCKOUT }_{i s j t}=\alpha_{1} \text { WalMart }_{j t}+\alpha_{1} \text { PreWM }_{j t}+X_{i s j} \beta+\phi_{j}+\omega_{s}+\psi_{t}+\varepsilon_{i s j t}
$$

where $S T O C K O U T_{i s j t}$ indicates whether product $i$ in store $s$, market $j$, and month $t$ is out of stock, WalMart $_{j t}$ indicates the presence of a Wal-Mart supercenter, and $\operatorname{PreWM}_{j t}$ indicates the two years before Wal-Mart enters. WalMart ${ }_{j t}$ reveals the impact of competition from Wal-Mart, and PreWM $\mathrm{P}_{j t}$ represents a Granger-type test for a pre-existing trend.

Equation (1) also includes a number of control variables. The term $X_{i s j}$ includes product, store, and market characteristics. Controls for product characteristics include whether the item is seasonal (i.e., not offered for sale year-round) and fixed effects for both the day of the week the item was sampled and the product category (e.g., eggs, cookies, frankfurters). Controls for store characteristics include whether the store is affiliated with a chain, total grocery selling space (categorized into 5 groups), and the distance from the warehouse that is the primary supplier of the outlet (categorized into 5 groups). ${ }^{14}$ Controls for local market characteristics include whether there is a competing store in the same census tract, the average income of residents of the census tract (categorized into 3 groups), and the proportion of these residents above the age of $65 .{ }^{15} \quad$ The term $\phi_{j}$ represents county fixed effects, which account for any fixed market characteristics that may have affected Wal-Mart's entry decision, such as unobserved consumer demographics. The term $\omega_{s}$ represents firm and/or store fixed effects, which account for any number of other fixed firm and store characteristics, such as the specific chain affiliation, exact location,

\footnotetext{
${ }^{12}$ The estimates in Table 6 also show that average stockout rates increased substantially between 1988 and 1998 in both types of markets. This may be explained by the secular increase in supermarkets product variety over this period. Product variety increased from an average of 26,000 SKUs per store in 1988 to 40,000 in 1998 (FMI 1989a, 1999a). Greater product variety increases the optimal stockout rate, because it makes stockouts more costly for firms to prevent and less costly for consumers to experience.

${ }^{13}$ Given the size of the data set and the large number of fixed effects, maximum likelihood estimation of a probit or conditional logit model is computationally infeasible.

${ }^{14}$ The total grocery selling space categories are: less than 10,000 square feet, 10,000 to $20,000,20,000$ to 30,000 , 30,000 to 40,000 , and 40,000 or more. The distance from warehouse categories are: less than 20 miles, 20 to 40, 40 to 75,75 to 125 , and 125 or more.

${ }^{15}$ The average income categories are: less than $\$ 40,000$ per year, $\$ 40,000$ to $\$ 55,000$, and $\$ 55,000$ or more.
} 
and store footprint. Finally, the term $\psi_{t}$ represents year-month fixed effects, which account for seasonal, technological, and other national trends in inventory management. The standard errors are adjusted to account for within-market correlation in the error term.

Table 6 reports ordinary least squares estimates of equation (1). Only the coefficients for the Wal-Mart indicators are reported; the estimates for the control variables are similar to the estimates reported in Table 2. The results confirm that competition from Wal-Mart leads competing supermarkets to offer greater product availability. Column (1) presents estimates from regressions that control for market fixed effects. On average, incumbent stores' stockout rates decrease by 30 basis points after WalMart enters a market $(p<0.10)$. Relative to the sample mean of 4.3 percent, this estimate corresponds to a 7 percent decrease in stockouts. If there is classical measurement error in the stockout estimates constructed from the CPI sample, then these coefficient estimates provide a lower bound for the magnitude of the true impact of competition from Wal-Mart.

Competition from Wal-Mart supercenters has been linked to the bankruptcy of at least 25 supermarket chains (Callahan and Zimmerman 2003). It is possible that exiting firms also performed relatively poorly before the shock. In this case, the correlation between competition from Wal-Mart and stockouts could be due to a composition effect; average quality would increase after competition intensifies, even if no incumbent firm actually improves its quality. To rule out this possibility, I repeat the regression analysis and include firm fixed effects. The results, which are reported in Column (2), find that stockout rates decrease by 40 basis points, or 9 percent of the mean, after Wal-Mart enters $(p<0.01)$. Controlling for firm fixed effects decreases the point estimate, suggesting that exiting firms have lower than average stockout rates. This is consistent with Wal-Mart posing a greater threat to large, chain supermarkets than niche independents (see Section 4). Across the sample, chain supermarkets average 16 basis point lower stockout rates than independents, and stockout rates are also negatively associated with store size (see Table 2).

Even some chains that were not pushed into bankruptcy likely closed some stores because of Wal-Mart's entry. If low quality stores with high stockout rates were more likely to close, then average supermarket quality would again increase, even if continuing stores did not actually increase their product availability. To assess the empirical relevance of this scenario, I re-estimate equation (1), this time also including separate fixed effects for each of the more than 11,000 stores included in the sample. These estimates, which are reported in Column (3), are based on same-store changes in the stockout rate after Wal-Mart entry. Even after adding these additional controls, competition from Wal-Mart is associated with a 34-basis-point, or 8 percent, decrease in the average stockout rate $(p<0.10)$. Relative to the samefirm analysis reported in Column (2), controlling for store fixed effects increases the point estimate slightly, suggesting that exiting stores did have slightly higher stockout rates than surviving stores at the 
same chains. Nevertheless, the estimates show definitively that continuing stores did increase their product availability after Wal-Mart enters.

The estimated increase in stockouts is economically meaningful. Applying the estimate from Table 6, Column (3) to the average industry stockout rate of 8.2 percent (Andersen 1996; Roland Berger 2002), implies that a household purchasing 50 items per week will encounter one fewer stockout about every three weeks. Based on the sample of firms that have at least 15,000 product availability observations, the estimated increase in stockouts is equal to 0.4 standard deviations. This effect would move a median firm to the 34th percentile of the stockout distribution.

An analysis of pre-existing trends shows no evidence that these firms or stores had unusually high or low levels of product availability in the two years before Wal-Mart entry. In all of the specifications reported in Table 6, the estimated pre-period coefficient is small and not statistically different from zero. The lack of a pre-existing trend suggests that the increase in competition indeed caused the observed increase in availability.

To buttress the interpretation that the competition-induced improvements in availability represent an intentional shift in product market strategy toward increased quality, it is important to rule out the possibility that they instead result unintentionally from the reduced store traffic associated with increased competition. If a store fails to accurately forecast the reduction in its residual demand after WalMart enters, then it will run out of inventory less frequently, even if it did not intend to reduce stockouts. It is impossible to distinguish these possibilities using only the basic difference-in-difference relations reported above. To tease them apart, I undertake three additional analyses: (1) I examine the duration of decrease in stockouts after Wal-Mart's entry; (2) I examine changes in a different dimension of supermarket quality - product variety; and (3) I examine whether stockouts of products whose inventories are controlled by the manufacturer also decrease (presented in Section 5.2). All of these analyses suggest that the improvements in product quality in fact represent an intentional strategic shift.

The impact of competition from Wal-Mart on supermarket product availability persists after entry. Figure 4 depicts the timing of the effects. I graph estimated regression coefficients associated with quarterly indicator variables for the eight quarters before and the eight quarters after Wal-Mart entry. These estimates are from analyses that control for store fixed effects and the other controls included the regression reported in Table 6, Column (3). On average, stockouts begin to decrease in the first quarter after entry and then stay at the lower level.

The extended duration of the impact of competition from Wal-Mart on product availability suggests that the improved in-stock rate reflects a strategic decision to increase inventory investment and improve product quality, rather than resulting from forecasting errors caused by Wal-Mart's entry. Using daily data, Singh, Hansen, and Blattberg (2006) find that when Wal-Mart enters, store traffic and sales 
drop immediately to the new equilibrium level. The decrease in store traffic implies that an optimizing retailer can now reduce inventories to achieve the same level of product availability. Although the magnitude of the change in store traffic is uncertain ex ante and may cause forecasting errors immediately after Wal-Mart enters, it becomes clear within the first few weeks and months. Competition-related errors in forecasting demand are therefore unlikely to persist past the first quarter, and almost certainly not past the second quarter after entry. The estimates presented in Figure 4 do not fit this pattern. In contrast, they show that the stockouts stay low for years after Wal-Mart enters. Increased competition appears to lead firms to make consistent and lasting improvements in product quality.

A supermarket's product availability is also affected by the variety of products it offers for sale. On the supply side, stock keeping unit (SKU) proliferation contributes to inventory shortfalls by increasing the size and complexity of the firm's forecasting problem. And on the demand side, running out of inventory may not be as costly for consumers when a store offers greater product variety. (In other words, the more products a store carries, the more difficulty it will have keeping everything in stock; but consumers won't mind so much if the store carries an acceptable substitute for an out-of-stock item.) So, if competition from Wal-Mart leads firms to reduce product variety, then the measured increases in product availability may not actually represent an improvement in product quality. To the contrary, however, competition from Wal-Mart seems to increase product variety.

Because I do not have direct measures of product variety, I construct a rough measure of changes in product variety from the CPI Commodity and Services Survey. Just as I can observe when a surveyor attempts to sample an item but encounters a stockout, I can observe when the sampled item is instead discontinued by the outlet (that is, marked as permanently unavailable). Product cancellations are rare for food items in the CPI sample, occurring in only 0.6 to 1.3 percent of attempted price quotes. ${ }^{16}$ While this measure of the product cancellation rate is far from perfect, I analyze it as a possible proxy for changes in product variety. ${ }^{17}$

Average changes in the product cancellation rate before and after highly leveraged transactions are presented in Figure 5. I graph estimated regression coefficients associated with quarterly indicator variables for the eight quarters before and after Wal-Mart entry. These estimates are from analyses that control for store fixed effects and the other controls included in Figure 4. There is no evidence of an

\footnotetext{
${ }^{16}$ The range on this estimate corresponds to details of how it is constructed. As explained in Appendix A, there is a possibility that the CPI data confuse out-of-stocks with product cancellations and vice versa. Considering all attempts to sample an item yields a product cancellation rate of 1.3 percent. As a conservative alternative, I only consider attempts for which the item was successfully sampled in the preceding month. This yields a lower estimate of 0.6 percent, and I use this algorithm to construct the variable in the analysis presented here.

17 The product cancellation rate is an asymmetric measure of product variety. It directly measures product cancellations, but it does not account for new product introductions. When I measure a decrease in product cancellation, it is possible that firms are also introducing fewer new products, thereby making fewer updates to their product mix while actually reducing product variety.
} 
increase in product cancellations after entry. To the contrary, although there is no pre-existing trend, product cancellations are less prevalent after competition from Wal-Mart increases.

Regression analyses of changes in product cancellations are reported in Table 7. These specifications are similar to those reported in Table 6, but with the different dependent variable. The estimates find that the product cancellation rate decreases by 8 to 13 basis points after Wal-Mart entry, corresponding to 13 to 22 percent decreases, relative to the mean $(p<0.05)$. Competition from Wal-Mart appears to spur improvements in quality for consumers through increased product variety in addition to increased availability. The fact that product variety also improves when competition intensifies reinforces the conclusion that the observed improvements in quality represent an intentional shift in product market strategy.

\section{B. Cross-sectional heterogeneity in the effect}

Cross-sectional heterogeneity in these effects across products, stores, and local markets presents further evidence that the observed changes in product quality are tied to the changes in retail competition. Grocery products are typically distributed by manufacturers to retail stores through either warehouse or direct store delivery (DSD). Major DSD product categories include carbonated drinks, bread, snacks, cookies, and crackers; other products typically have warehouse distribution.

A primary difference between warehouse and DSD distribution is that the manufacturer's distributor typically plays the lead role in store-level category management, merchandising, and managing the shelf inventory for DSD products. ${ }^{18}$ The degree of the retailers' involvement in inventory management depends on the replenishment arrangement in place with the distributor. Although the retailer always checks-in and approves deliveries when they arrive, the retailer often does not initiate orders. In some arrangements, the route driver doubles as a salesperson who monitors the shelf and replenishes as needed; in others, an account manager for the distributor forecasts sales requirements and works with the store manager to develop an order for the store. These arrangements give the distributor a good deal of autonomy over replenishment. Because DSD distributors typically have incentives based on total brand sales across stores, inventory levels for DSD products are more likely to reflect incentives faced by the manufacturer rather than the retailer.

As discussed in Section 2, an increase in retail competition is unlikely to affect the optimal level of product availability from the perspective of most manufacturers. In contrast to retailers, manufacturers' profits are very sensitive to customers substituting brands upon encountering an out-of-

\footnotetext{
${ }^{18}$ There are also differences in the nature of products distributed through each channel. Compared to warehousesupplied items, DSD products tend to have shorter shelf life, higher volume, higher promotional intensity (and demand variability), lower value density, and greater merchandising difficulty due to greater weight or fragility (Boston Consulting Group 1998).
} 
stock item, but they are largely insensitive to the risk of customers switching stores, because manufacturers earn roughly similar profits regardless of where their products are sold. (In fact, the Robinson-Patman Act limits wholesale price discrimination.) Because manufacturers do not share stores' incentive to offer greater product availability when retail competition increases, competition is unlikely to affect inventories or the availability of DSD products.

I estimate the effect of competition from Wal-Mart separately for product categories that are typically distributed through a warehouse versus direct store delivery. Panel estimates of equation (1) with store fixed effects are reported in Table 8. While the average stockout rate for warehouse-supplied categories decreases by 38 basis points after Wal-Mart entry (Column 3; $p<0.05$ ), the prevalence of stockouts does not increase for DSD categories (Column 2). The DSD point estimate is positive and not statistically different than zero. Given the distributors' active role in DSD replenishment, the differential impact of competition on the availability of warehouse-supplied products provides a useful robustness test that the increase in stockouts reflects retailers' incentives to prevent store switching, rather than some other unobserved, concomitant shock to demand or consumer preferences. These results thereby also provide further evidence that the competition-induced improvements in availability represent an intentional shift in product market strategy toward increased quality.

As discussed in Section 4, Wal-Mart's entry into groceries was widely perceived as a greater threat to supermarket chains than to niche independents. As a further test that supermarkets' changes in product quality after Wal-Mart entry are tied to the changes in retail competition, I examine whether the associated reductions in stockouts are in fact concentrated among chain stores.

Estimates of the impact of competition from Wal-Mart on stockouts of warehouse-supplied products in chain versus independent stores are also presented in Table 8. Stores are classified as chain or independent based on the industry definition of 11 or more stores, and both regressions include store fixed effects and the other controls included in equation (1). The results show a large impact on product availability at chain stores. The stockout rate for warehouse-supplied products in chain stores decreases by 57 basis points after Wal-Mart entry (Column 5; $p<0.01$ ), whereas the estimated change among independent stores is positive and not statistically different than zero (Column 4).

The largest chains display the strongest effects. Restricting this analysis to chains of 1,000 or more stores, the stockout rate decreases by 102 basis points after Wal-Mart entry, with a standard error of 40 basis points $(p<0.05)$. This amounts to a decrease in stockouts of 22 percent, relative to the mean rate of 4.6 percent for these stores. This dramatic increase in quality contrasts with these firms' muted price response to Wal-Mart entry. Basker and Noel (forthcoming) find that price cuts are less than half as large among large chains as among other stores. Combined, these stockout and price results support case studies finding that supermarket chains attempt to differentiate themselves from Wal-Mart by improving 
quality levels and offering wider selection, rather than competing purely on price (Carré, Tilly, and Holgate 2009).

A final test also suggests that supermarkets' changes in product quality after Wal-Mart entry result from the changes in retail competition. Because Wal-Mart caters to low income consumers, supermarkets located in lower income areas within a given supercenter's catchment area are likely to be most affected when a supercenter opens. I classify supermarkets based on the median income of the census tract in which they are located (the average Wal-Mart catchment area contains 16 census tracts), and compare the quality reactions of firms in the top and bottom quartiles for median income. Building on the previous results, I also restrict the sample to warehouse-supplied products in chain stores.

Estimates of the impact of competition from Wal-Mart on stores in high and low income areas are also presented in Table 8. The results show the greatest impact among stores located in low income areas. The stockout rate decreases by 107 basis points in low income areas after Wal-Mart entry (Column 7; $p<$ 0.01). This amounts to a 24 percent reduction in stockouts, relative to the mean rate of 4.5 percent for these stores. In contrast, the stockout rate decreases by only 14 basis points in high income area after Wal-Mart entry (Column 6). This point estimate, which is not statistically significant, corresponds to only a 3 percent reduction relative to the mean.

The decrease in stockouts rates among stores in low income areas is dramatic. Applying the estimate from Column (7) to the average industry stockout rate of 8.2 percent (Andersen 1996; Roland Berger 2002), implies that the average household, which purchases about 50 items per week (FMI 1999a, 2000b), will average one fewer stockout a week - a significant improvement in quality. Based on the sample of firms that have at least 15,000 product availability observations, the decrease in stockouts is equal to 1.3 standard deviations. This effect would move a median firm to the 8th percentile of the stockout distribution.

In sum, these estimates reveal that the reduction in stockouts associated with competition from Wal-Mart is greatest for warehouse-supplied products, for chain stores, and in low-income areas. These patterns all point to competitive pressure encouraging improvements in product quality.

\section{Conclusions}

Product quality is an important element of competition in a wide range of markets, including the supermarket industry. Although firms with differentiated products compete on many dimensions, relatively little empirical research focuses on competition's impact on nonprice variables. In theory, competition can either increase or decrease quality, depending on how it affects the sensitivity of demand to changes in quality (for example, see Spence 1975). If price competition leads to a quality race to the bottom, then the welfare gains from competition may actually be much lower than if quality were 
unaffected (Chamberlain 1953). Identifying the relationship between competition and quality is thus an important empirical question.

This study specifically examines the connection between competition and a supermarket's provision of retail product availability - a key strategic variable in the retail sector. I find that competition improves this dimension of quality for consumers. Stores facing competition in their census tract have 5 percent lower stockout rates than other stores. Moreover, stockout rates among incumbent supermarkets decrease by 8 percent, on average, when a Wal-Mart supercenter opens nearby. The effect is long-lived, restricted to products whose inventory is controlled by the retailer, and joined by a concomitant increase in product variety, all indicating that the additional stockouts are not attributable to decreases in store traffic or demand miscalculations following Wal-Mart's entry. Instead, the improvements in availability seem to represent an intentional shift in product market strategy toward increased quality. The effect is larger for chain stores and in low income areas, where competition from Wal-Mart is particularly intense. In these stores, stockout rates decrease by a striking 24 percent. This estimate is actually a lower bound for the magnitude of the true effect, because the analyzed stockout rates, which I estimate from CPI microdata, are likely measured with error.

There is intense public debate about the effects of Wal-Mart on local communities. Hundreds of grassroots organizations across the country fight to keep Wal-Mart supercenters and other big box retailers out of their communities, and local governments across the country have adopted limits on store size or other regulations meant to deter Wal-Mart's entry (Beaumont and Tucker 2002). But the estimates reported in this paper suggest that benefits of Wal-Mart for consumers extend beyond its low prices. Not only does the competitive pressure Wal-Mart creates lower prices at competing stores (Hausman and Leibtag 2007; Basker and Noel, forthcoming), it also improves their product availability. In fact, by this measure, supermarket quality improves the most in the poorest local markets, where consumers are arguably the most in need. This analysis of course does not speak to Wal-Mart's other effects on communities, including any effects on jobs, traffic, crime, or social capital.

The intuition that firms with market power can maximize their profits by reducing the quality of their products is often cited but rarely tested empirically. Competition policy also tends to focus relatively little attention on quality competition. Based on product availability in the supermarket industry, the analyses presented in this paper suggest that pressure from competition can have substantial effects on product quality in real markets. I find that supermarkets that are most at risk of losing sales to Wal-Mart display a 1.3 standard deviation improvement in product availability when Wal-Mart enters nearby. This effect would move a median firm to the 8th percentile of the stockout distribution - a significant improvement for consumers. And to the extent that the impact on stockouts is representative of firms' investments in other dimensions of quality, the benefits of competition for consumers may be 
much greater. Examining the impact of competition on other dimensions of product quality would be an interesting area for further empirical research.

References

Abbott, Lawrence. 1955. Quality and Competition; an Essay in Economic Theory. New York: Columbia University Press.

Andersen Consulting. 1996. Where to Look for Incremental Sales Gains: The Retail Problem of out-ofStock Merchandise. Coca-Cola Retailing Research Council.

Anderson, Eric T., Gavan J. Fitzsimons, and Duncan Simester. 2006. "Measuring and Mitigating the Costs of Stockouts." Management Science, 52(11): 1751-63.

Anupindi, Ravi, Maqbool Dada, and Sachin Gupta. 1998. "Estimation of Consumer Demand with Stock-out Based Substitution: An Application to Vending Machine Products." Marketing Science, 17(4): 406-23.

Basker, Emek. 2005. "Job Creation or Destruction? Labor Market Effects of Wal-Mart Expansion." Review of Economics and Statistics, 87(1): 174-83.

. 2007. "The Causes and Consequences of Wal-Mart's Growth." Journal of Economic Perspectives, 21(3): 177-98.

. Forthcoming. "Does Wal-Mart Sell Inferior Goods?" Economic Inquiry.

, and Michael Noel. Forthcoming. "The Evolving Food Chain: Competitive Effects of Wal-Marts Entry into the Supermarket Industry." Journal of Economics and Management Strategy

Beaumont, Constance, and Leslie Tucker. 2002. "Big-Box Sprawl (and How to Control It)." Municipal Lawyer, 43(2): 6-9, 30-31.

Bils, Mark. 2005. "Studying Price Markups from Stockout Behavior."

Boston Consulting Group. 1998. "The Power of DSD: Delivering Growth in Sales, Profits, and Productivity," Progressive Grocer. Special Report.

Brooks, B.L. 1972. "Inventory Management and Control." University of Illinois Extension Circular, 1063.

Callahan, Patricia, and Ann Zimmerman. 2003. "Price War in Aisle 3 - Wal-Mart Tops Grocery List with Supercenter Format; but Fewer Choices, Amenities," Wall Street Journal, May 27.

Carré, Françoise, Chris Tilly, and Brandynn Holgate. 2009. "Competitive Strategies in the Us Retail Industry: Consequences for Jobs in Food and Consumer Electronics Stores," Industry Studies Association Annual Conference. Chicago, Ill.

Chamberlin, Edward H. 1933. The Theory of Monopolistic Competition. Cambridge Mass: Harvard 
Univ. Press.

Dana, James, and Nicholas Petruzzi. 2001. "The Newsvendor Model with Endogenous Demand." Management Science, 47(11): 1488-97.

Dana, James D. 2001. "Competition in Price and Availability When Availability Is Unobservable." RAND Journal of Economics, 32(3): 497-513.

Domberger, Simon, and Avrom Sherr. 1989. "The Impact of Competition on Pricing and Quality of Legal Services." International Review of Law and Economics, 9(1): 41-56 Language English Available From Publisher's URL.

Dorgan, Tim. 1997. "The Awful Truth," Progressive Grocer. 75.

Draganska, Michaela, Michael J. Mazzeo, and Katja Seim. 2009. "Addressing Endogenous Product Choice in an Empirical Analysis of Merger Effects," Northwestern University.

Ellickson, Paul B. 2006. "Quality Competition in Retailing: A Structural Analysis," International Journal of Industrial Organization, 24(3): 521-40.

Emmelhainz, Margaret, James R. Stock, and Larry W. Emmelhainz. 1991. "Consumer Responses to Retail Stock-Outs." Journal of Retailing, 67(2): 138-47.

Fitzsimons, Gavan J. 2000. "Consumer Response to Stockouts." Journal of Consumer Research, 27(2): 249-66.

Food Marketing Institute (FMI). Various years (a). The Food Marketing Industry Speaks. Washington D C: Food Marketing Institute.

- Various years (b). Trends in the United States: Consumer Attitudes and the Supermarket. Washington, DC: Food Marketing Institute.

Gaur, Vishal, and Young-Hoon Park. 2007. "Asymmetric Consumer Learning and Inventory Competition." Management Science, 53(2): 227-40.

Gruen, Thomas W., Daniel S. Corsten, and Sundar Bharadwaj. 2002. Retail out-of-Stocks: A Worldwide Examination of Extent, Causes, and Consumer Responses. Washington, DC: Grocery Manufacturers of America.

Hall, Joseph, and Evan Porteus. 2000. "Customer Service Competition in Capacitated Systems." Manufacturing \& Service Operations Management, 2(2): 144-65.

Hausman, Jerry, and Ephraim Leibtag. 2007. "Consumer Benefits from Increased Competition in Shopping Outlets: Measuring the Effect of Wal-Mart," Journal of Applied Econometrics, 22(7): 1157-77.

Holmes, Thomas J. 2001. "Bar Codes Lead to Frequent Deliveries and Superstores." RAND Journal of Economics, 32(4): 708-25. . 2008. "The Diffusion of Wal-Mart and Economies of Density," NBER Working Paper 13783.

Jia, Panle. 2008. "What Happens When Wal-Mart Comes to Town: An Empirical Analysis of the Discount Retailing Industry." Econometrica, 76(6): 1263-316. 
Matsa, David A. 2009. "Financial Leverage and Product Quality: Evidence from the Supermarket Industry," Northwestern University.

Mazzeo, Michael J. 2003. "Competition and Service Quality in the U S Airline Industry." Review of Industrial Organization, 22(4): 275-96.

National Grocers Association. 2003. "NGA Marketing Survey."

Peckham, James O. 1963. "The Consumer Speaks." Journal of Marketing, 27(4): 21-6.

Pew Research Center for the People and the Press. 2005. "Wal-Mart: A Good Place to Shop but Some Critics Too," Pew Research Center for the People and the Press.

Progressive Grocer. 1968. "The Out of Stock Study: Part I," S1-S16.

Roland Berger Strategy Consultants. 2002. Full-Shelf Satisfaction--Reducing out-of-Stocks in the Grocery Channel: An in-Depth Look at DSD Categories. Washington, DC: Grocery Manufacturers of America.

Schmalensee, Richard. 1979. "Market Structure, Durability, and Quality: A Selective Survey." Economic Inquiry, 17(2): 177-96.

Singh, Vishal P., Karsten T. Hansen, and Robert C. Blattberg. 2006. "Market Entry and Consumer Behavior: An Investigation of a Wal-Mart Supercenter." Marketing Science, 25(5): 457-76.

Spence, A. Michael. 1975. "Monopoly, Quality, and Regulation." Bell Journal of Economics, 6(2): 41729.

Straughn, Katherine. 1991. "The Relationship between Stockouts and Brand Share," Tallahassee, FL: Florida State University.

Warner, Melanie. 2006. "When Wal-Mart Shops for Groceries, It Gets Whatever It Wants," New York Times, March 3. 


\section{A1. Data appendix}

\section{A. Retail stockouts}

The data on retail stockouts are from the CPI Commodity and Services Survey, which is used by the U.S. Bureau of Labor Statistics (BLS) to compute the consumer price index (CPI). To calculate the CPI, the BLS sends surveyors to record the prices of about 30,000 items sold at grocery stores each month, where each price is specific to a particular product at a particular establishment. Generally, a product must be available for purchase at the time the surveyor visits the establishment in order to be included in the CPI. If the product is unavailable for sale, the surveyor determines whether the establishment expects to carry the item in the future. In this sense, a product may be considered out of stock if it is not available for sale, it is continuing to be carried by the outlet, and it is not seasonally unavailable (Bils 2005).

In practice, the determination of a stockout is slightly more subtle. First, I condition on the outlet being available for pricing by the BLS surveyor. Second, I consider items with different day prices as being out of stock at the time of the surveyor's visit. Third, I restrict attention to observations that are at least three months prior to a product becoming permanently or seasonally unavailable. This is an attempt to address a concern that an item reported as temporarily unavailable that becomes permanently unavailable before another price quote is successfully obtained may not actually represent a stockout (Bils 2005). ${ }^{19}$

For food items (excluding food consumed away from home), surveyors are instructed to record an item as available if the retailer respondent says an out-of-stock item will be restocked later that day. This complicates efforts to measure true product availability. Out-of-stocks caused by retailers failing to stock shelves with back room or display inventory will not be reflected in the BLS data. Industry studies attribute 8 to 22 percent of out-of-stocks to these sorts of store shelving issues (Andersen 1996; Gruen et al. 2002).

In some situations it is also possible that a BLS surveyor may record an out-of-stock item as available if another similar item is available for purchase. However, the procedures for this sort of substitution are regulated carefully by the BLS. Key characteristics of the product must be the same for

\footnotetext{
${ }^{19}$ The concern is that the BLS surveyor may initially misinterpret some product cancellations as temporary out-ofstocks. A concern in the opposite direction is that some products that are repeatedly unavailable because they are out of stock may become classified as permanently unavailable. If a product is repeatedly unavailable, it may trigger an instruction to the surveyor to begin pricing a new item at the next visit. However, analysis conducted by Teague Ruder and cited by Bils (2005) suggests that in practice the field agents often continue to price the old version when the product becomes available for purchase before a substitution is executed. Accepting the surveyors' original classification of product unavailability yields an estimated out-of-stock rate of 5.3 percent. Another option is to only count an item as temporarily out-of-stock if it is observed to be available at a later date. Under this definition, I eliminate the final observation for each product, because out-of-stock rates for those observations are zero by construction. This methodology results in an overall out-of-stock rate of 4.3 percent. The paper uses this more conservative algorithm for computing an out-of-stock.
} 
the surveyor to execute a substitution. For example, a substitute ready-to-eat cereal product must have the same brand, product name, size, sweeteners, fruit, nuts, flavorings, and more, but it does not have to have the same UPC code. To the extent that the BLS definition of a stockout more closely reflects a consumer's willingness to substitute across nearly identical items (e.g., changes in package design), it may be preferred to a simple SKU-based definition.

\section{B. Store and market characteristics}

Store-level data on ownership, sales volume, selling area, and the primarily warehouse supplier of each U.S. supermarket is from the Trade Dimensions Retail Site Database. The Retail Site Database is a leading source of establishment data in the retail food industry. I use cross-sections of the Retail Site Database from 1990, 1995, 2000, and 2004, merging the monthly CPI data with the nearest available information from the Retail Site Database. I merge the data sets using the store telephone number, ZIP code, street address, and/or name. I am able to successfully match Retail Site Database information to 89.2 percent of the observations of product availability.

Market demographic information on each store's census tract is from the 2000 U.S. Census of Population and Housing. Census tracts typically have between 2,500 and 8,000 residents and are designed to be homogeneous with respect to population characteristics, economic status, and living conditions (U.S. Census Bureau, Geographic Areas Reference Manual, April 19, 2000). Summary statistics for the store and market characteristics analyzed are reported in Table 1.

\section{Supermarket quality ratings}

Supermarket quality ratings are from the September 1993, August 1997, September 2000, September 2003, and October 2006 issues of Consumer Reports magazine. Each chain for which ratings are reported is evaluated by at least 200 readers, and some chains are evaluated by more than 1,500 readers. CPI data from January 1990 through December 2004 are matched temporally with the ratings whose survey was conducted closest to the observation on product availability. Reflecting the design of the Consumer Reports survey, CPI data are included only for stores in each supermarket chain that bear the corporate name. 
Figure 1: Stockout Rate by Day of the Week

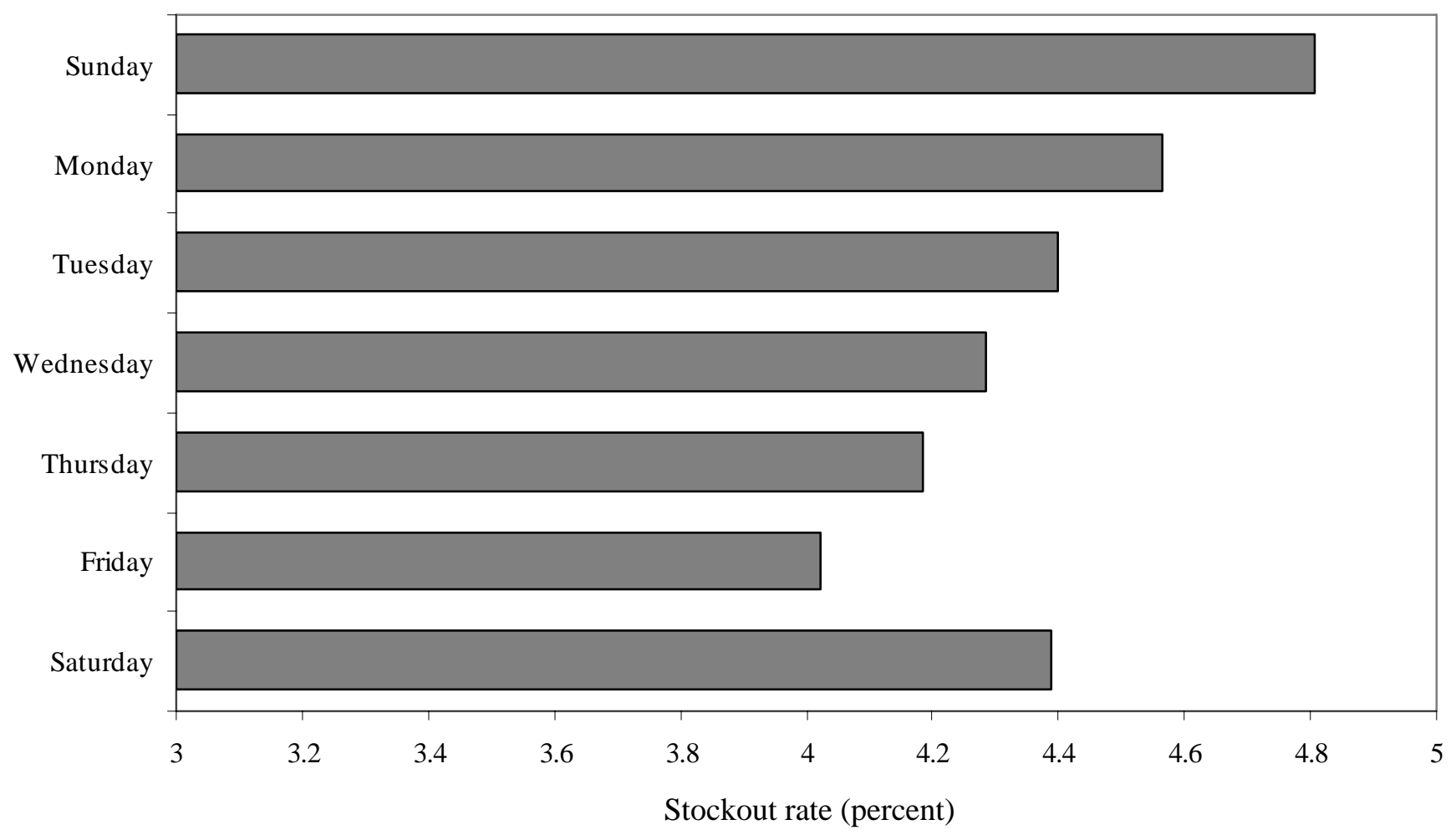


Figure 2: Stockout Rate by Major Product Group

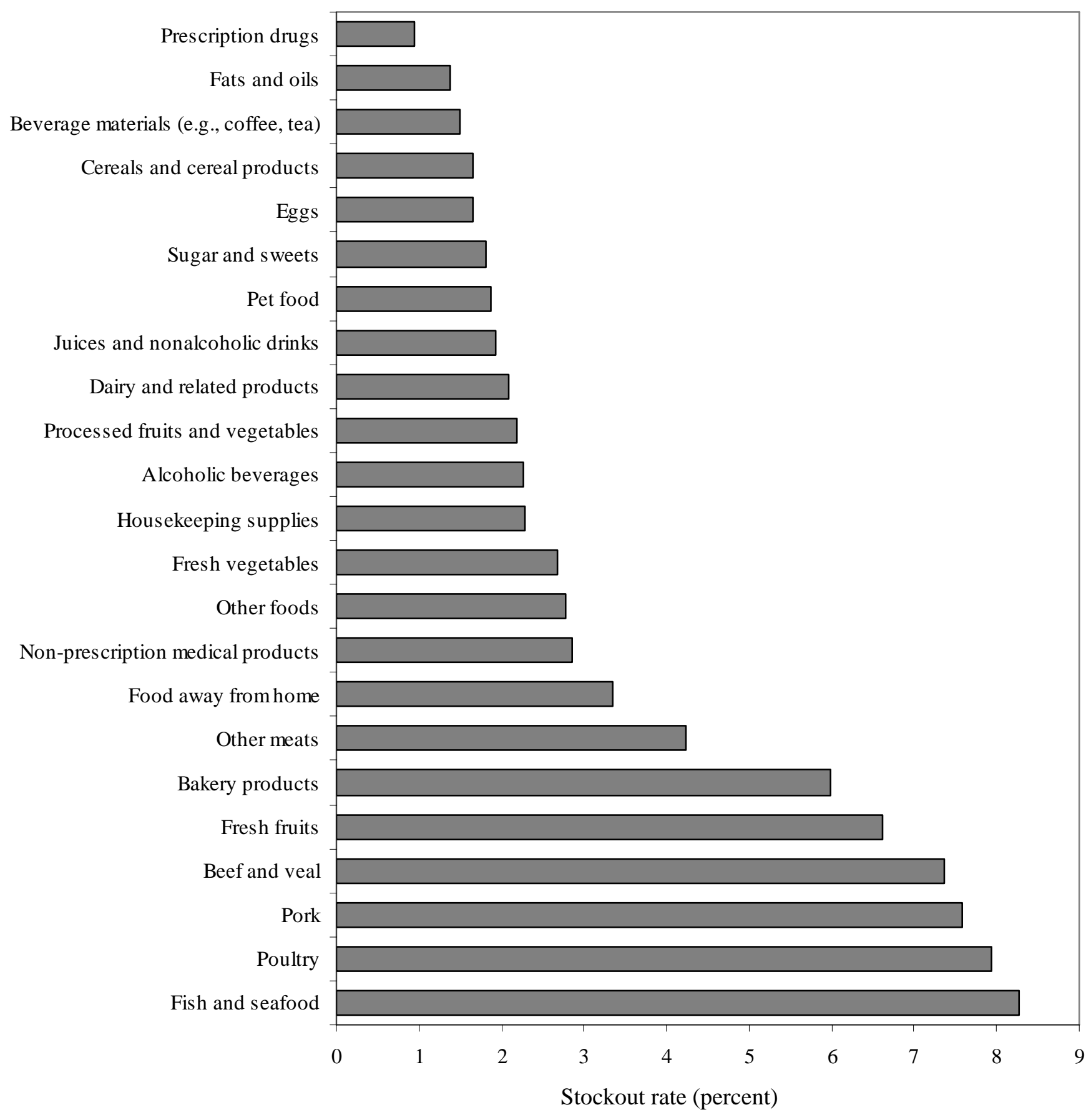


Figure 3: Wal-Mart Supercenter Entry into New Markets, 1988-2004

Number of new markets entered

(Combined annual market size, \$ billion)

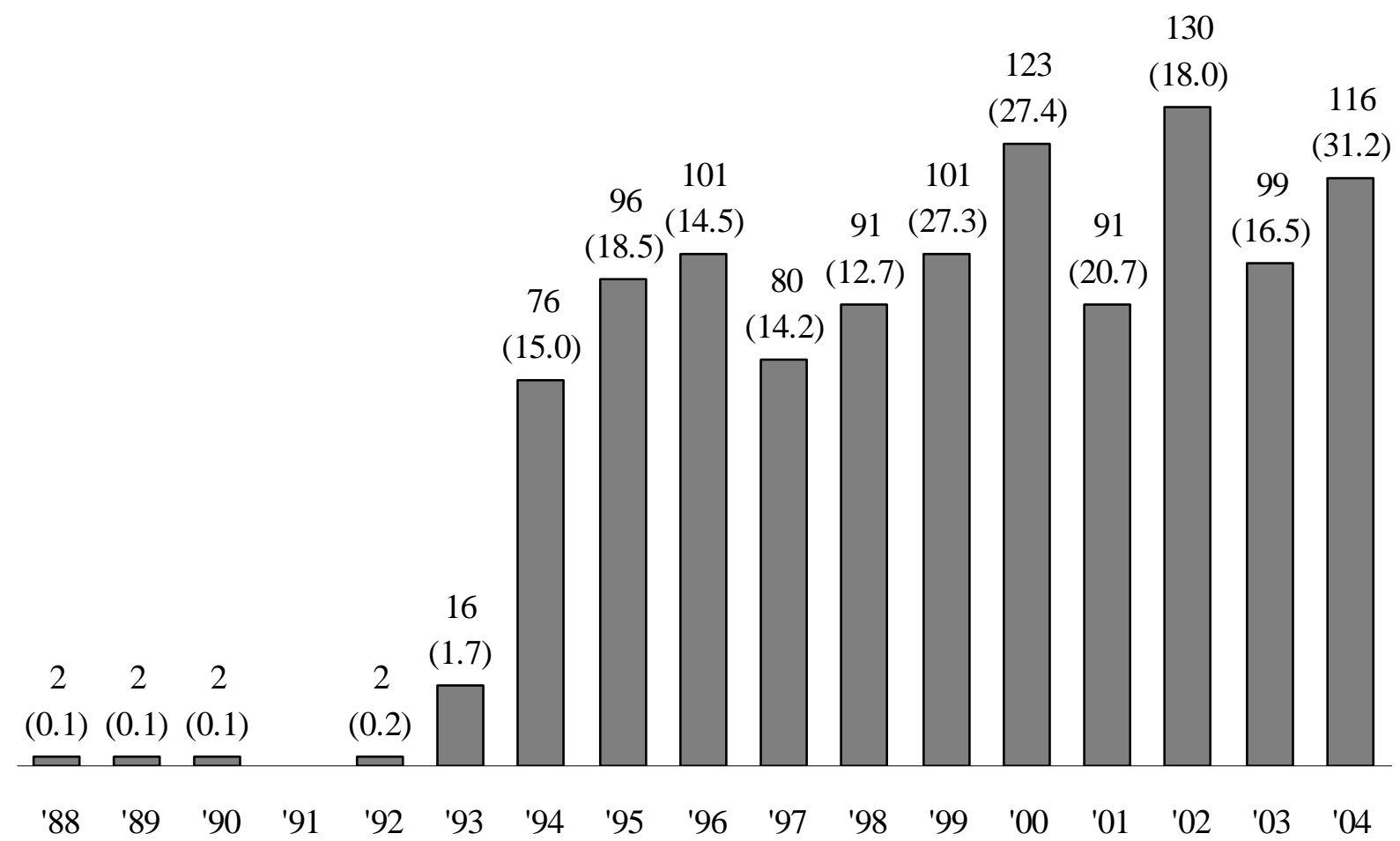

Sources: Thomas Holmes (2008); Trade Dimensions Retail Site Database; author's analysis 
Figure 4: Changes in Stockout Rates After Wal-Mart Entry

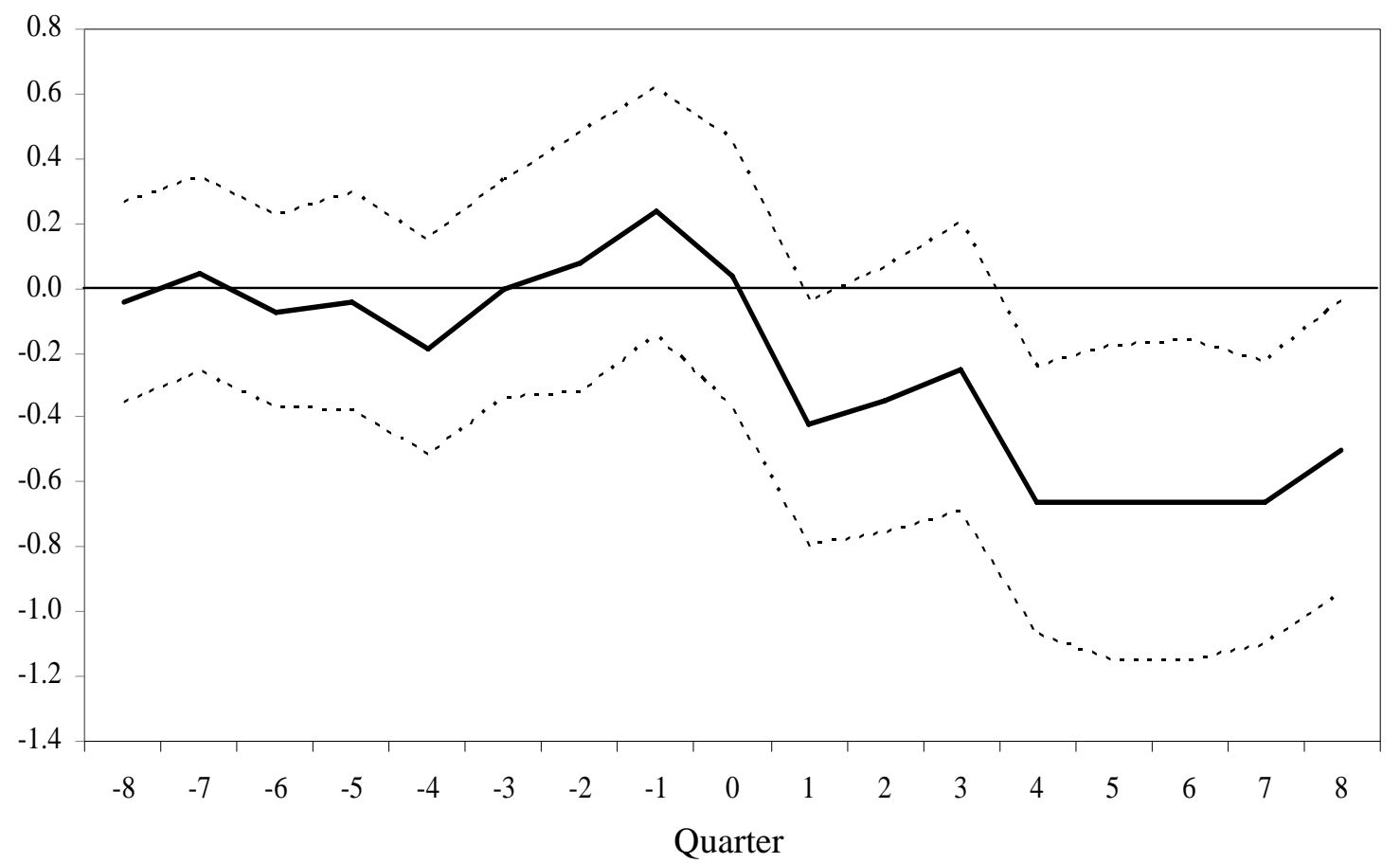

Note: This figure depicts regression coefficients and 95 percent confidence intervals from a regression examining the probability of an item being out of stock. An indicator for whether the item is out of stock (multiplied by 100) is regressed on separate indicators for each of the eight quarters before and after Wal-Mart enters a store's county, store fixed effects, and a set of additional controls. The reported coefficients should be interpreted as the percentage point change in the stockout rate associated with each indicator variable. In addition to store fixed effects, the controls include the product, store, and time characteristics included in the regressions reported in Table 6, Column 3. The mean stockout rate in this sample is 4.3 percent. 
Figure 5: Changes in Product Cancellation Rates After Wal-Mart Entry

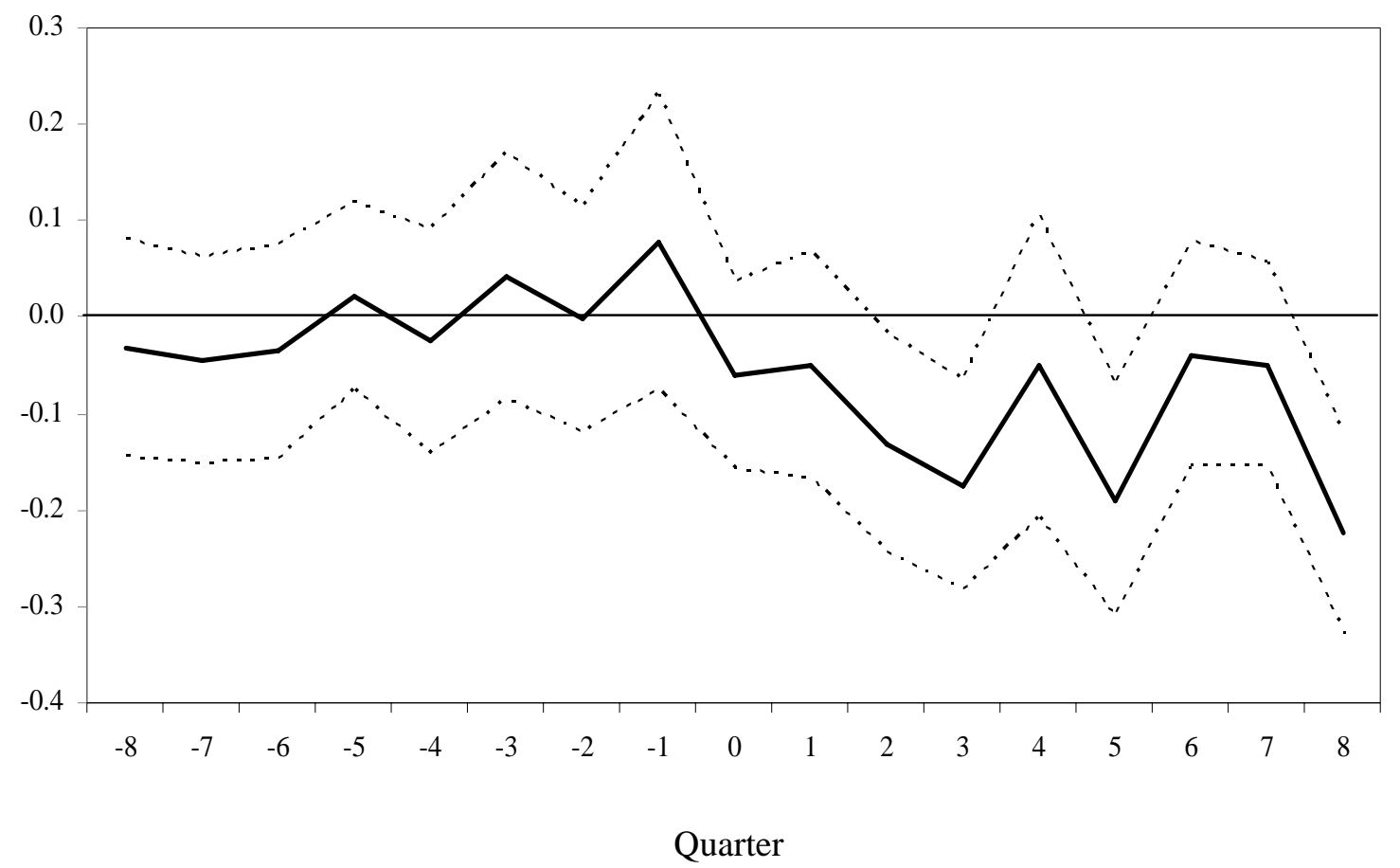

Note: This figure depicts regression coefficients and 95 percent confidence intervals from a regression examining the probability of an item being discontinued by a retail outlet. An indicator for whether the item is discontinued (multiplied by 100) is regressed on separate indicators for each of the eight quarters before and after Wal-Mart enters a store's county, store fixed effects, and a set of additional controls. The reported coefficients should be interpreted as the percentage point change in the product cancellation rate associated with each indicator variable. In addition to store fixed effects, the controls include the product, store, and time characteristics included in the regressions reported in Table 7, Column 3. The mean product cancellation rate in this sample is 0.6 percent. 
Table 1

Summary Statistics

\begin{tabular}{|c|c|}
\hline & Mean \\
\hline \multicolumn{2}{|l|}{ Outcome measure: } \\
\hline Out of stock & $4.3 \%$ \\
\hline \multicolumn{2}{|l|}{ Market characteristics: } \\
\hline Competition in census tract & 38.6 \\
\hline \multicolumn{2}{|l|}{ Average income of local residents (\$ thousands): } \\
\hline 55 or more & 23.3 \\
\hline 40 through 54 & 28.2 \\
\hline Less than 40 & 48.5 \\
\hline Percent of local residents aged $65+$ & 14.0 \\
\hline \multicolumn{2}{|l|}{ Store characteristics: } \\
\hline \multicolumn{2}{|l|}{ Grocery selling space (1,000 sq. ft.): } \\
\hline 40 or more & 32.7 \\
\hline 30 through 39 & 23.9 \\
\hline 20 through 29 & 23.1 \\
\hline 10 through 19 & 12.6 \\
\hline Less than 10 & 7.7 \\
\hline Affiliated with a chain (11 or more stores) & 81.1 \\
\hline \multicolumn{2}{|l|}{ Distance from primary supplier (miles): } \\
\hline 125 or more & 15.0 \\
\hline 75 through 124 & 15.7 \\
\hline 40 through 74 & 19.3 \\
\hline 20 through 39 & 19.4 \\
\hline Less than 20 & 30.6 \\
\hline Integrated with primary supplier & 61.1 \\
\hline \multicolumn{2}{|l|}{ Product characteristic: } \\
\hline Seasonal item (not offered for sale year-round) & 4.0 \\
\hline Observations & $4,751,180$ \\
\hline
\end{tabular}

Note: This table reports summary statistics for the main analytic sample. For indicator variables, the mean equals the percent of observations with the corresponding characteristic. 
Table 2

Stockout Rates and Market, Store, and Product Characteristics

\begin{tabular}{cc} 
Coefficient estimate & Standard error \\
\hline$-0.21^{* * *}$ & 0.07 \\
$-0.60^{* * *}$ & 0.12 \\
$-0.23^{* *}$ & 0.09 \\
$-1.59^{* * *}$ & 0.59 \\
$-0.45^{* * *}$ & \\
$-0.32^{* *}$ & 0.13 \\
-0.13 & 0.14 \\
0.02 & 0.12 \\
\end{tabular}

Distance from primary supplier (miles):

125 or more

0.15

0.15

75 through 124

0.19

0.15

40 through 74

$-0.38 * * *$

0.13

20 through 39

$-0.22 * *$

0.10

Seasonal item

$3.70 * * *$

0.24

Observations

4,751,180

R-squared

0.03

Fixed effects:

Firm

X

Product category

$\mathrm{X}$

Metropolitan area

Day of week

$X$

Year-month

$\mathrm{X}$

$\mathrm{X}$

Notes: This table reports coefficient estimates and standard errors from a linear probability regression of a grocery item being out of stock. Each observation represents a market-store-product-month. An indicator for whether the item is out of stock (multiplied by 100) is regressed on market, store, and product characteristics. The reported coefficients should be interpreted as the percentage point change in the stockout rate associated with a unit increase in the indicated variable. In addition to the reported coefficients, the regressions include fixed effects for firm, product category, metropolitan area, day of week, and year-month. Standard errors, corrected for within-market correlation, are reported. The mean stockout rate in this sample is 4.3 percent.

*** Significant at the 1 percent level

** Significant at the 5 percent level 
Table 3

Stockout Rates and Other Dimensions of Supermarket Quality

(1)

$-0.06 * * *$

Overall rating

(100-point scale)

Cleanliness

(5-point scale)

Courtesy

(5-point scale)

Checkout speed

(5-point scale)

Observations

R-squared

Fixed effects:

Product category

Metropolitan area

Day of week

Year-month

Market, product, and

store characteristics
(2)

(3)

(4)
$-0.24 * *$

$-0.32 * * *$

(0.10)

$-0.32 * *$

$2,173,051$

0.01

$2,173,051$

0.01

$1,863,479$

0.01

$1,863,479$

0.01
$\mathrm{X} \quad \mathrm{X}$

X $X$

X $\quad X$

X $\mathrm{X}$

X $\quad X$
$\mathrm{X}$

$\mathrm{X}$

$\mathrm{X}$

$\mathrm{X}$

$\mathrm{X}$
$\mathrm{X}$

$\mathrm{X}$

$\mathrm{X}$

$\mathrm{X}$

$\mathrm{X}$

Notes: This table reports coefficient estimates and standard errors from linear probability regressions of a grocery item being out of stock. An indicator for whether the item is out of stock (multiplied by 100) is regressed on various ratings of supermarket chains from Consumer Reports magazine, as well as a set of controls. The reported coefficients should be interpreted as the percentage point change in the stockout rate associated with a unit increase in the indicated rating. The overall rating (Column 1) is measured on a 100point scale (min. 63, max. 87), and the other ratings (Columns 2-4) are on a 5-point scale. On both scales, a higher rating indicates better performance. There are fewer observations in Columns 3 and 4, because separate ratings for courtesy and checkout speed are not available for the survey results published in October 2006. The controls include all of the covariates reported in Table 2 and and fixed effects for product category, metropolitan area, day of week, and year-month. Standard errors, corrected for within-chain variation, are reported in parentheses. The mean stockout rate is 4.5 percent in Columns 1 and 2, and 4.3 percent in Columns 3 and 4.

*** Significant at the 1 percent level

** Significant at the 5 percent level 
Table 4

Firm and Store Characteristics for Wal-Mart and Incumbent Stores

\begin{tabular}{cccc}
\multicolumn{3}{c}{ Grocery stores, 1990 } & Wal-Mart \\
\cline { 1 - 2 } Full sample & Eventually face & Do not face & supercenters, \\
& Wal-Mart entry & Wal-Mart entry & 2004 \\
\hline
\end{tabular}

\begin{tabular}{|c|c|c|c|c|}
\hline \multicolumn{5}{|l|}{ A. Store characteristics: } \\
\hline Grocery selling space (1,000 sq ft) & 22.6 & 24.2 & 20.2 & 62.6 \\
\hline & $(14.4)$ & $(14.8)$ & $(13.4)$ & $(10.5)$ \\
\hline \multirow[t]{2}{*}{ Weekly grocery volume $(\$ 1,000)$} & 171.0 & 175.8 & 164.1 & 880.4 \\
\hline & $(143.8)$ & $(142.6)$ & $(145.3)$ & $(286.7)$ \\
\hline \multirow[t]{2}{*}{ Employment (FTEs) } & 49.9 & 51.1 & 48.1 & 332.8 \\
\hline & $(45.0)$ & $(45.2)$ & $(44.7)$ & $(94.8)$ \\
\hline \multirow[t]{2}{*}{ Checkout counters } & 7.40 & 7.56 & 7.16 & 27.85 \\
\hline & (3.98) & (3.90) & $(4.07)$ & $(6.02)$ \\
\hline \multirow{2}{*}{$\begin{array}{l}\text { Percent affiliated with chain } \\
\text { (11 or more stores) }\end{array}$} & 56.5 & 59.4 & 52.3 & 100 \\
\hline & $(49.6)$ & $(49.1)$ & $(49.9)$ & \\
\hline \multicolumn{5}{|l|}{ B. Firm characteristics: } \\
\hline \multirow[t]{2}{*}{ Stores in chain } & 269.8 & 285.2 & 247.3 & 1,675 \\
\hline & $(438.5)$ & $(449.2)$ & $(421.5)$ & \\
\hline \multirow[t]{2}{*}{ States with at least one store } & 6.16 & 6.08 & 6.27 & 46 \\
\hline & $(8.66)$ & $(8.30)$ & $(9.16)$ & \\
\hline Observations & 32,065 & 19,053 & 13,012 & 1,675 \\
\hline
\end{tabular}

Notes: This table reports the means and standard deviations (in parentheses) of various store and firm characteristics in 1990 (the first year for which the data are available) for incumbent stores in markets that eventually experience entry from a Wal-Mart supercenter. For comparison, the characteristics are also reported (i) for stores in markets that do not experience Wal-Mart entry and (ii) for Wal-Mart supercenters that openned by 2004 (the last year for which the data are available). The data on firm and store characteristics are from Trade Dimensions, and the information on Wal-Mart entry are from Thomas Holmes (2008). 
Table 5

Difference-in-Difference Estimate

\begin{tabular}{ccc}
\hline & & \\
& 1988 & 1998 \\
\cline { 2 - 3 } & & \\
Experience entry between & & \\
$\begin{array}{l}1988 \text { and 1998? } \\
\text { Yes }\end{array}$ & 3.03 & 4.00 \\
& $(0.16)$ & $(0.21)$ \\
No & {$[65]$} & {$[63]$} \\
& 3.14 & 5.05 \\
& $(0.10)$ & $(0.14)$ \\
& {$[255]$} & {$[283]$} \\
Difference & & $-1.05^{* * *}$ \\
& -0.11 & $(0.31)$ \\
Difference-in-difference & $(0.21)$ & $-0.94^{* *}$ \\
& & $(0.39)$ \\
\hline
\end{tabular}

Notes: This table reports mean stockout rates (in percentage points) and the associated standard errors (in parentheses) at two points in time for two samples: (1) markets that experienced Wal-Mart entry between 1988 and 1998; and (2) firms that did not. The number of markets underlying each calculation is reported in brackets, and the reported mean stockout rates are weighted by the number of product availability observations. The third line reports the difference in mean stockout rates between these two samples in each year, and the final line reports the simple difference-in-difference estimate.

*** Significant at the 1 percent level

** Significant at the 5 percent level 
Table 6

Changes in Stockout Rates Following Wal-Mart Entry

\begin{tabular}{lccc}
\hline & & & \\
& & $(1)$ & $(3)$ \\
\cline { 2 - 4 } & & & \\
After entry & $-0.30^{*}$ & $-0.40^{* * *}$ & $-0.34^{*}$ \\
& $(0.17)$ & $(0.17)$ & $(0.18)$ \\
2 years before entry & & & \\
& -0.07 & -0.05 & -0.03 \\
& $(0.13)$ & $(0.13)$ & $(0.13)$ \\
Observations & & & \\
R-squared & $4,751,180$ & $4,751,180$ & $0.751,180$ \\
Fixed effects: & 0.03 & 0.04 & \\
County & & & $\mathrm{X}$ \\
Firm & & $\mathrm{X}$ & $\mathrm{X}$ \\
Store & $\mathrm{X}$ & $\mathrm{X}$ & $\mathrm{X}$ \\
Product category & & $\mathrm{X}$ & $\mathrm{X}$ \\
Day of week & $\mathrm{X}$ & $\mathrm{X}$ & $\mathrm{X}$ \\
Year-month & $\mathrm{X}$ & $\mathrm{X}$ & $\mathrm{X}$ \\
Market, product, and & $\mathrm{X}$ & $\mathrm{X}$ & \\
store characteristics & $\mathrm{X}$ & &
\end{tabular}

Notes: This table reports coefficient estimates and standard errors from regressions examining the probability of an item being out of stock. Each observation represents a market-store-product-month. An indicator for whether the item is out of stock (multiplied by 100) is regressed on separate indicators for (1) whether Wal-Mart operates a supercenter in the county and (2) the 2 years before Wal-Mart entry, as well as a set of controls. The reported coefficients should be interpreted as the percentage point change in the stockout rate associated with each indicator variable. The controls include county, product category, day of week, and year-month fixed effects as well as indicators for whether the store faces competition in its census tract, the income of local residents, store size, distance from primary supplier, and whether the item is seasonal. The controls also include firm and store fixed effects where indicated. Standard errors, corrected for within-market correlation, are reported in parentheses. The mean stockout rate in this sample is 4.3 percent.

*** Significant at the 1 percent level

* Significant at the 10 percent level 
Table 7

After entry

2 years before entry

Observations

R-squared

Fixed effects:

County

Firm

Store

Product category

Day of week

Year-month

Market, product, and

store characteristics
(1)

(2)

(3)

$-0.13 * * *$

$-0.12 * * *$

$-0.08^{* *}$

$-0.04$

$-0.03$

0.01

(0.03)

4,447,253

4,447,253

0.004

4,447,253

0.009

Notes: This table reports coefficient estimates and standard errors from regressions examining the probability of an item being discontinued by a retail outlet. Each observation represents a market-storeproduct-month. An indicator for whether the item is discontinued (multiplied by 100) is regressed on separate indicators for (1) whether Wal-Mart operates a supercenter in the county and (2) the 2 years before Wal-Mart entry, as well as a set of controls. The reported coefficients should be interpreted as the percentage point change in the product cancellation rate associated with each indicator variable. The controls include county, product category, day of week, and year-month fixed effects as well as indicators for whether the store faces competition in its census tract, the income of local residents, store size, distance from primary supplier, and whether the item is seasonal. The controls also include firm and store fixed effects where indicated. Standard errors, corrected for within-market correlation, are reported in parentheses. The mean product cancellation rate in this sample is 0.6 percent.

*** Significant at the 1 percent level

** Significant at the 5 percent level 
Table 8

Changes in Stockout Rates Following Wal-Mart Entry, by Distribution Channel, Chain Affiliation, and Market Affluence

\begin{tabular}{|c|c|c|c|c|c|c|c|}
\hline & (1) & $(2)$ & (3) & (4) & (5) & (6) & (7) \\
\hline Products' distribution channel: & All & DSD & Warehouse & Warehouse & Warehouse & Warehouse & Warehouse \\
\hline Stores' chain affiliation: & All & All & All & Independent & Chain & Chain & Chain \\
\hline Census tracts' median income: & All & All & All & All & All & High & Low \\
\hline After entry & $\begin{array}{l}-0.34 * \\
(0.18)\end{array}$ & $\begin{array}{c}0.34 \\
(0.66)\end{array}$ & $\begin{array}{c}-0.38^{* *} \\
(0.19)\end{array}$ & $\begin{array}{c}0.13 \\
(0.49)\end{array}$ & $\begin{array}{c}-0.56^{* * *} \\
(0.20)\end{array}$ & $\begin{array}{l}-0.14 \\
(0.52)\end{array}$ & $\begin{array}{c}-1.07 * * * \\
(0.41)\end{array}$ \\
\hline 2 years before entry & $\begin{array}{l}-0.03 \\
(0.13)\end{array}$ & $\begin{array}{l}-0.05 \\
(0.46)\end{array}$ & $\begin{array}{l}-0.02 \\
(0.13)\end{array}$ & $\begin{array}{l}-0.21 \\
(0.34)\end{array}$ & $\begin{array}{l}-0.02 \\
(0.15)\end{array}$ & $\begin{array}{l}-0.11 \\
(0.37)\end{array}$ & $\begin{array}{l}-0.31 \\
(0.29)\end{array}$ \\
\hline Observations & $4,751,180$ & 341,351 & $4,409,829$ & 833,928 & $3,575,901$ & 890,602 & 896,201 \\
\hline R-squared & 0.05 & 0.06 & 0.05 & 0.05 & 0.05 & 0.05 & 0.05 \\
\hline \multicolumn{8}{|l|}{ Fixed effects: } \\
\hline County, Firm, and Store & $\mathrm{X}$ & $\mathrm{X}$ & $\mathrm{X}$ & $X$ & $\mathrm{X}$ & $\mathrm{X}$ & $\mathrm{X}$ \\
\hline Product category & $\mathrm{X}$ & $\mathrm{X}$ & $\mathrm{X}$ & $\mathrm{X}$ & $\mathrm{X}$ & $\mathrm{X}$ & $\mathrm{X}$ \\
\hline Day of week & $\mathrm{X}$ & $\mathrm{X}$ & $\mathrm{X}$ & $\mathrm{X}$ & $\mathrm{X}$ & $\mathrm{X}$ & $\mathrm{X}$ \\
\hline Year-month & $\mathrm{X}$ & $\mathrm{X}$ & $\mathrm{X}$ & $\mathrm{X}$ & $\mathrm{X}$ & $\mathrm{X}$ & $\mathrm{X}$ \\
\hline $\begin{array}{l}\text { Market, product, and } \\
\text { store characteristics }\end{array}$ & $\mathrm{X}$ & $\mathrm{X}$ & $\mathrm{X}$ & $\mathrm{X}$ & $\mathrm{X}$ & $\mathrm{X}$ & $\mathrm{X}$ \\
\hline
\end{tabular}

Notes: This table reports coefficient estimates and standard errors from within-store regressions examing the probability of an item being out of stock for different subsets of products and stores. The reported coefficients should be interpreted as the percentage point difference in the stockout rate associated with undertaking a highly leverage transaction. For details on the econometric specification, see Table 6, Column 3. Each column represents estimates from a different subsample of products, stores, and/or local markets. Products are separated based on whether they are typically delivered by a manufacturer's distributor directly to the store (DSD) or through a warehouse. Products in the following categories are classified as DSD: carbonated drink, bread, snacks, cookies, and crackers (Boston Consulting Group 1998). Stores are separated based on whether they are part of a chain of 11 or more stores. Local markets are separated based on whether residents of the census tract have mediam income in the top quartile ("high") or bottom quartile ("low").

*** Significant at the 1 percent level

** Significant at the 5 percent level

* Significant at the 10 percent level 
Cereals and cereal products

Flour and prepared flour mixes

Breakfast cereal

87,19

$1.6 \%$

Rice, pasta, cornmeal

72,728

Bakery products

Bread

98,926

5.7

Fresh biscuits, rolls, and muffins

35,827

7.2

Cakes and cupcakes (excluding frozen)

26,453

10.0

Cookies

38,429

3.5

Crackers and bread \& cracker products

26,773

2.1

Sweetrolls, coffee cake \& doughnuts (excluding frozen)

20,677

9.6

Frozen bakery products \& frozen/refrigerated doughs \& batters

17,055

3.1

Pies, tarts, turnovers (excluding frozen)

8,375

Beef and veal

Uncooked ground beef

$81,958 \quad 2.5$

Uncooked beef roasts

157,266

10.0

Uncooked beef steaks

234,208

6.0

Uncooked other beef and veal

57,124

12.5

Pork

Bacon, breakfast sausage, and related products

Ham

80,853

13.2

Pork chops

65,122

3.5

Other pork including roasts and picnics

71,098

10.6

Other meats

Frankfurters

25,094

3.1

Lunchmeats

127,272

3.7

Lamb, organ meats, and game

14,865

10.4

Poultry

Chicken

170,786

7.2

Other poultry including turkey

23,286

13.1

Fish and seafood

Fresh fish and seafood

61,626

14.0

Processed fish and seafood

71,726

Eggs

Eggs

80,220

Dairy and related products

Milk

Cheese and cheese products

156,108

Ice cream and related products

86,354

2.5

Other dairy and related products

67,595

2.8

44,156

Fresh fruits

Apples

110,294

Bananas

79,693

0.7

Citrus fruits

125,925

Other fresh fruits

260,183

Fresh vegetables

Potatoes

78,988

2.6

Lettuce

93,895

Tomatoes

78,520

Other fresh vegetables including fresh herbs

154,978

Processed fruits and vegetables

Canned fruits and vegetables

39,264

Frozen fruits and vegetables

96,766

Other processed fruits and vegetables including dried

95,784 


\begin{tabular}{|c|c|c|}
\hline & Observations & Stockout rate \\
\hline \multicolumn{3}{|l|}{ Juices and nonalcoholic drinks } \\
\hline Carbonated drinks & 79,779 & 1.3 \\
\hline Frozen noncarbonated juices and drinks & 62,921 & 1.6 \\
\hline Nonfrozen noncarbonated juices and drinks & 111,871 & 2.5 \\
\hline \multicolumn{3}{|l|}{ Beverage materials } \\
\hline Coffee & 79,465 & 1.3 \\
\hline Tea & 22,606 & 1.7 \\
\hline Other beverage materials & 27,447 & 1.7 \\
\hline \multicolumn{3}{|l|}{ Sugar and sweets } \\
\hline Sugar and artificial sweeteners & 59,976 & 1.4 \\
\hline Candy and chewing gum & 44,696 & 2.3 \\
\hline Other sweets & 32,356 & 1.9 \\
\hline \multicolumn{3}{|l|}{ Fats and oils } \\
\hline Butter and margarine & 59,080 & 1.5 \\
\hline Salad dressing & 78,942 & 1.5 \\
\hline Peanut butter & 26,390 & 0.9 \\
\hline Other fats and oils & 23,011 & 1.2 \\
\hline \multicolumn{3}{|l|}{ Other foods } \\
\hline Soups & 70,080 & 2.0 \\
\hline Frozen and freeze dried prepared foods & 83,965 & 4.4 \\
\hline Snacks & 76,005 & 3.8 \\
\hline Salt and other seasonings and spices & 17,909 & 1.6 \\
\hline Olives, pickles, relishes & 11,948 & 1.9 \\
\hline Sauces and gravies & 35,870 & 1.9 \\
\hline Other condiments (excluding olives, pickles and relishes) & 14,211 & 1.5 \\
\hline Baby food & 40,802 & 1.9 \\
\hline Prepared salads & 11,263 & 3.2 \\
\hline Other miscellaneous foods & 50,621 & 1.9 \\
\hline \multicolumn{3}{|l|}{ Food away from home } \\
\hline Food from vending machines and mobile vendors & 9,089 & 3.3 \\
\hline \multicolumn{3}{|l|}{ Alcoholic beverages } \\
\hline Beer, ale, and other malt beverages & 21,439 & 1.9 \\
\hline Distilled spirits & 6,543 & 1.8 \\
\hline Wine & 16,447 & 2.9 \\
\hline \multicolumn{3}{|l|}{ Housekeeping supplies } \\
\hline Laundry and cleaning products & 41,080 & 2.1 \\
\hline Household paper products & 17,418 & 2.2 \\
\hline Miscellaneous household products & 9,000 & 3.1 \\
\hline \multicolumn{3}{|l|}{ Prescription drugs } \\
\hline Prescription drugs & 6,753 & 0.9 \\
\hline \multicolumn{3}{|l|}{ Non-prescription medical products } \\
\hline Internal and respiratory over-the-counter drugs & 10,589 & 2.7 \\
\hline Topicals and dressings & 5,097 & 3.1 \\
\hline \multicolumn{3}{|l|}{ Pet food } \\
\hline Pet food & 12,992 & 1.9 \\
\hline Overall & $4,751,180$ & 4.3 \\
\hline
\end{tabular}

Note: This table reports the number of observations and the mean stockout rate by product category for the main analytic sample. The product categories are listed under their major product group reported in Figure 1. 